\title{
Methodology for Documentation and Sustainability of Cultural Heritage Landscapes: The Case of the Tajos de Alhama (Granada, Spain)
}

\author{
María del Carmen Vílchez-Lara *D, Jorge Gabriel Molinero-Sánchez and Concepción Rodríguez-Moreno
}

check for

updates

Citation: Vílchez-Lara, M.d.C.;

Molinero-Sánchez, J.G.;

Rodríguez-Moreno, C. Methodology

for Documentation and Sustainability of Cultural Heritage Landscapes: The Case of the Tajos de Alhama

(Granada, Spain). Sustainability 2021,

13, 12964. https://doi.org/10.3390/ su132312964

Academic Editor: John Carman

Received: 15 October 2021

Accepted: 19 November 2021

Published: 23 November 2021

Publisher's Note: MDPI stays neutral with regard to jurisdictional claims in published maps and institutional affiliations.

Copyright: (c) 2021 by the authors. Licensee MDPI, Basel, Switzerland. This article is an open access article distributed under the terms and conditions of the Creative Commons Attribution (CC BY) license (https:/ / creativecommons.org/licenses/by/ $4.0 /)$.
Department of Architectural and Engineering Graphic Expression, University of Granada, 18071 Granada, Spain; jmolinero@ugr.es (J.G.M.-S.); conrodriguezmoreno@gmail.com (C.R.-M.)

* Correspondence: mariacarmenvl@ugr.es

\begin{abstract}
This research aims to start the process of the revitalization of peri-urban spaces with high landscape and cultural potential, dotted with a series of heritage landmarks that allude to the recent industrial, economic and cultural history of the region, currently semi-degraded or abandoned, as is the case with the impressive and steep miller landscape of the Tajos de Alhama de Granada. To achieve this, it is proposed to carry out a comprehensive documentation (historical, cartographic, planimetric, photographic and photogrammetric) of the study area since, until now, there were no similar research studies. The application of an organized and structured method of work, documentation and diagnosis using the tools and graphic techniques of the 21st century has offered extensive results that have been turned into a rigorous and systematic catalog. This catalog will serve as the basis for the promotion of integrated action plans for the recovery of this urban edge, with the triple objective of the rehabilitation of buildings of architectural interest, rehabilitation of the surrounding public space and consolidation of the historic complex that makes up the mills, the river, the landscape and the city. We conclude that the enhancement of the cultural heritage landscape of the Tajos and the guidelines provided for the rehabilitation of its historic water mills, with possible compatible uses (tourist, cultural or administrative), will favor the conservation and sustainable revitalization of such an exceptional heritage site.
\end{abstract}

Keywords: heritage; landscape; Tajos de Alhama; Granada; graphical documentation; survey; photogrammetry; conservation; revitalization

\section{Introduction}

The Real Academia Española (RAE) defines tajo as "escarpa alta y cortada casi a plomo" [1], which, in English, corresponds to the word gorge, defined according to the Cambridge Dictionary as "a deep, narrow valley with steep sides, usually formed by a river or stream cutting through hard rock" [2]. In Alhama de Granada, also known as the city of the Tajos, we have a good example of this definition thanks to the impressive geographical accident that appears before our eyes as we reach the town. This scar in the landscape is crossed by the Alhama River, also called Marchán, which leaves in its path, on both banks, poplars, willows, farmland, etc., configuring a place with special characteristics that make it unique.

The Tajos de Alhama heritage landscape was declared a Picturesque Site in 1975 due to its extraordinary beauty, placing it at the same level as the cities of Ronda and Cuenca [3]. It is registered as Bien de Interés Cultural (highest level of patrimonial protection in Spain) within the Historic Site of Alhama [4], declared as a Natural Monument of Andalusia [5] and included as an Outstanding Landscape in the general catalog of the Andalusian Historical Heritage [6] (p. 150).

This imposing breach, dotted with a series of heritage landmarks, practically completely surrounds the historic-artistic center of Alhama. We are facing a territory in which 
natural and cultural aspects coexist and complement each other, while assets of a diverse nature are integrated:

- Cultural heritage: the natural landscape as an indissoluble image and identifying element of Alhama;

- Architectural heritage: water mills, aqueducts, ditches;

- Movable heritage: machinery associated with mills;

- Intangible and ethnological heritage: milling, which, even though it is an extinct trade, can be recovered at the museum level.

Despite the recognition of the Tajos as a landscape of special relevance that must be conserved and protected, at present, there are hardly any defined development, conservation and enhancement strategies [7], so it is immersed in a progressive state of abandonment and semi-degradation, especially its old water mills.

The main purpose of this research is to initiate the path towards the recovery and revitalization of the Tajos peri-urban space, with high landscape and cultural potential, offering a detailed analysis of its elements at both a global and individual level. The graphic and written documentation obtained allows us to analyze the existing heritage and be the basis for any future restoration and sustainable recovery of this asset of cultural interest.

Due to the great extension and different nature of the existing assets in the studied landscape, we have applied a highly structured methodological organigram. This has consisted of an in-depth review of the primary historical sources and exhaustive field work for the registration of the heritage elements, as well as for their photographic survey and their photogrammetric reconstruction.

\section{Study Area}

\subsection{Geographic Contextualization}

Alhama de Granada is located in the west of Granada province (Figure 1) in the area known as Tierras de Alhama, or the Temple, the latter named in honor of a Muslim family that settled in this area [8] (p. 19). This region forms a topographic step, defined by hills of little slope, between the depression of the Granada plain and the powerful limit of the Tejeda, Almijara and Alhama mountains, belonging to the Penibética mountain range, on the border with the province of Malaga. The main organizing axis of the settlements in the territory is made up of the Alhama and Cacín Rivers, which are born in the Sierra de Almijara [9] and flow from south to north towards the Genil River.

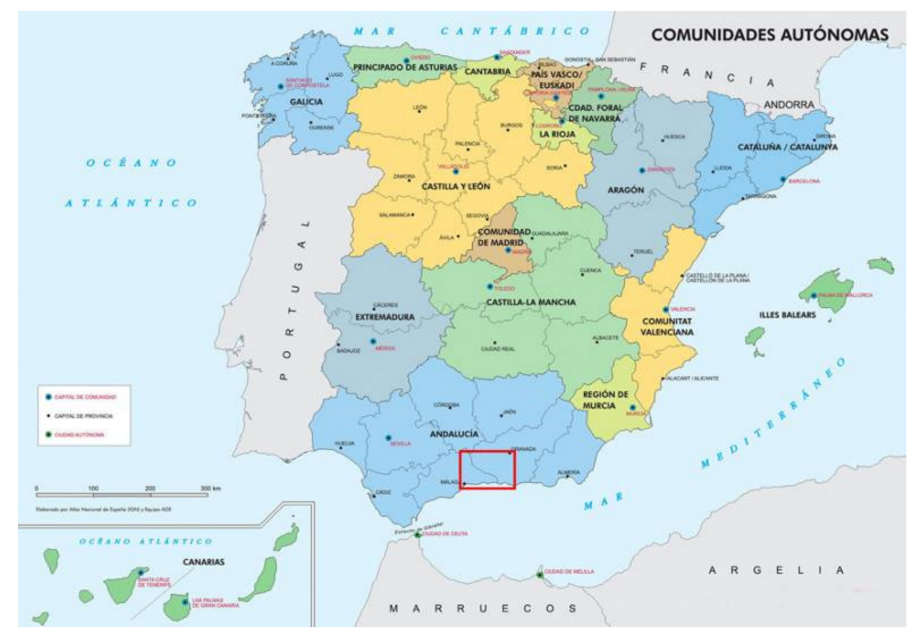

Figure 1. Location of the area known as Tierras de Alhama, between the Spanish provinces of Granada and Malaga.

If the river courses determine the interior pattern of occupation, no less important are the natural and historical walkways between Malaga and Granada, such as the prehistoric 
Zafarraya or the pre-Roman Alhama, making Alhama a key element in the territorial articulation of eastern Andalusia [10] (p. 605) (Figure 2).
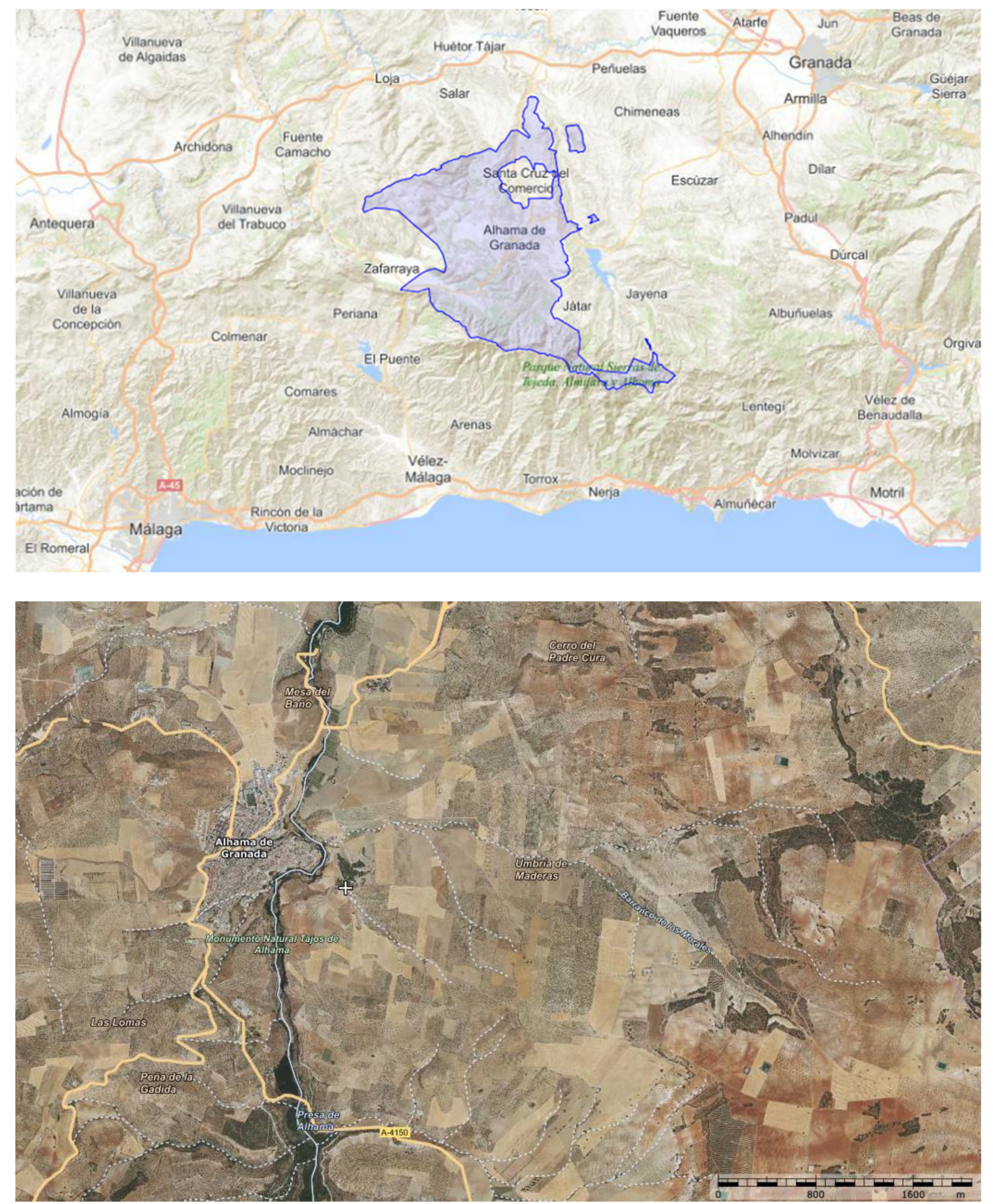

Figure 2. Alhama de Granada region. Instituto Geográfico Nacional.

\subsection{The Miller Landscape}

The natural and cultural landscape values of the Tajos are inseparable both from the settlement of the city of Alhama and from the series of constructions scattered along the Marchán River and the irrigation canals, which led the water to the hydraulic mills located at the bottom of the escarpment valley. The presence of water allowed not only the appearance of water mills linked to the trade of cereal milling but also the irrigation of existing crops in the river valley. Thanks to the documentary source from the 18th century, the Catastro del Marqués de la Ensenada [11], we know of the former existence of eleven hydraulic mills next to the Marchán River, reduced to seven according to the Diccionario de Pascual Madoz [12], in the middle of the 19th century. 
In this research project, we focus on the five mills that are located on the side of the Tajo as it passes through the town of Alhama, all fed by the general canal or Caz del Molino. From south to north, these mills correspond to the flour factories of San Francisco, San Pedro, la Purísima, Santa Teresa y Nuestra Señora del Carmen (Figure 3). They are constructions from the late nineteenth or early twentieth centuries, with almost all certainty built on other pre-existing ones, which hardly differ from rural architecture. There was an essential determining factor in their location, always next to a river course, and exterior features that identify them, such as the vaults under which the water runs [13].

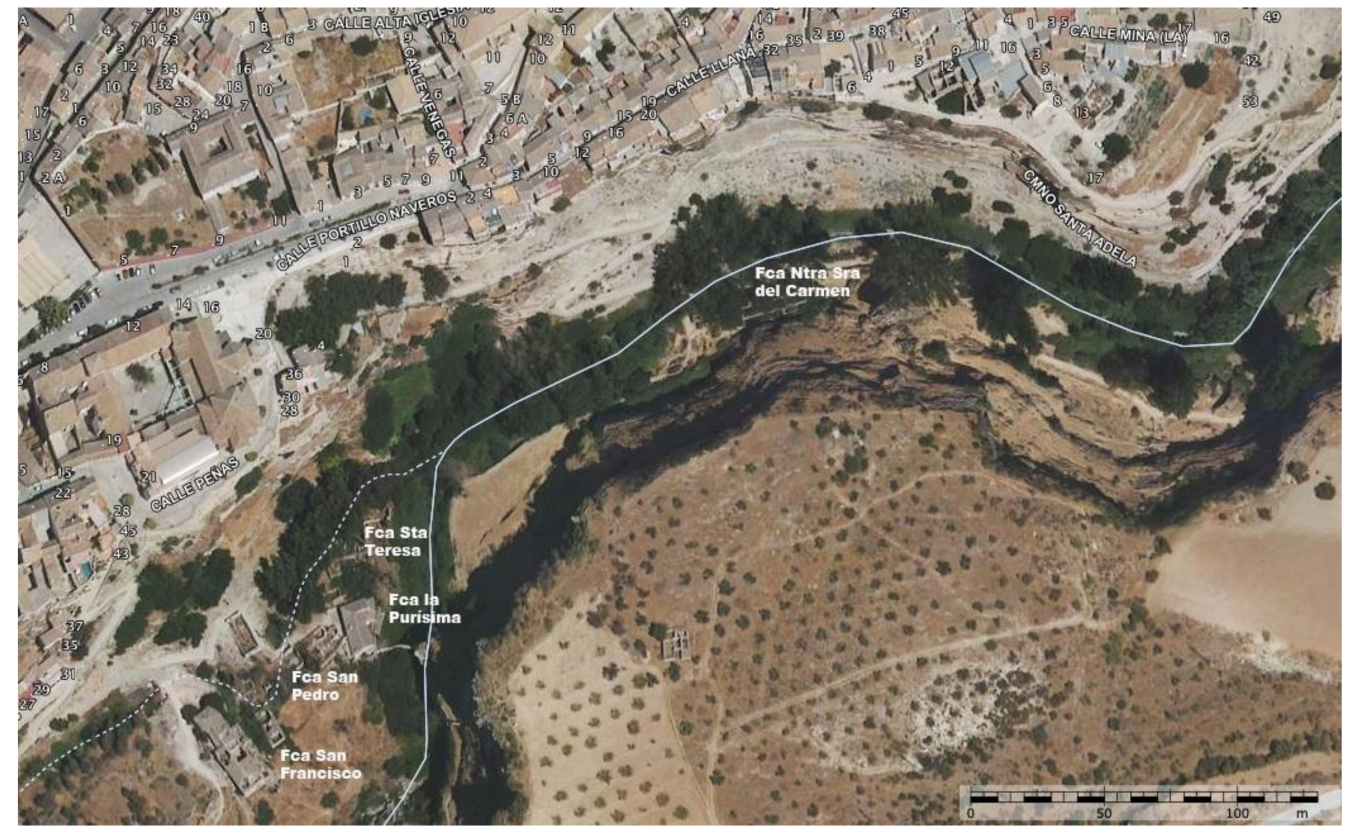

Figure 3. Location of the five mills next to the Alhama River, in the Tajos. Base plan of the Instituto Geográfico Nacional.

The reason for placing the mill next to a river stream was to take advantage of the force of the water to move the hydraulic device, which would convert the cereal grains into flour. In the Renaissance, Juanelo Turriano graphically and textually described the operation of a water mill with a horizontal wheel [14], which will be the one used in the mills of Alhama (Figure 4).

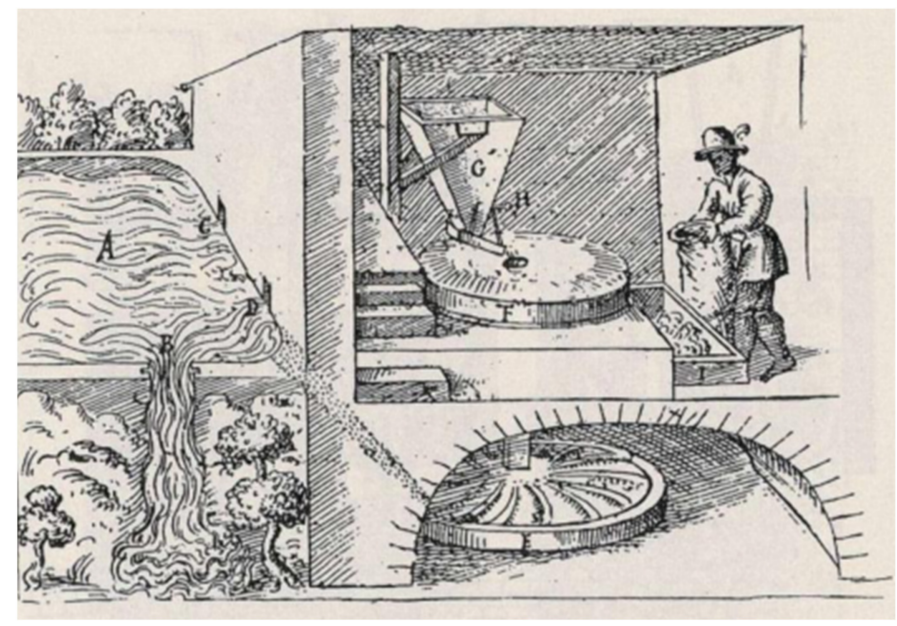

Figure 4. Operation of a horizontal wheel mill, circa 1564 (Juanelo Turriano) [14]. 
The mill was generally divided into two parts, one for the home of the miller and his family and the other for the manufacture of flour. The structure was constituted by very thick load bearing walls and pillars, which supported the wooden round timbers of the floor and the roof trusses. The operation of this type of mill was based, following the grinding process, on depositing the grain in the hopper, which descended through a chute towards the eye of the millstone, where two grinding wheels, one fixed and the other mobile, turned it into flour [15].

In the 19th century, the mills were replaced by factories, these being different from the mills, which provided the service of grinding wheat to the peasants in exchange for an economic benefit or in kind, while the raw material (wheat, rye, etc.) in the factories was stored with different machines, the cereal grains were processed and, finally, a packaged product (flour) was sold [16] (p. 4). The manufacturing activity of Alhama ended with the closure of the factories of the Tajos during the 1970s and only one of them is currently conserved in a good state, both the building and of the machinery that follows harboring. This is the Fábrica de Harinas la Purísima, converted into a museum thanks to the determined and continuous effort of its owners, the Castro family. [17]. The other four mills are currently abandoned and in a progressive process of ruin, silent witnesses of what was and has died, extremely fragile and in need of actions based on sustainable criteria aimed at their recovery and proper management. As stated by Papapietro, the commitment to the sustainability of the interventions in the cultural landscapes of the industrial heritage must be understood as the balance of three basic aspects: environmental, social and economic [18].

\section{Materials and Methods}

We are facing a field of research of great extension and complexity, where heritage assets of different nature and chronology coexist and are related. For this reason, the methodology followed has required a precise organigram for the organization of the research work and structuring of the actions carried out:

1. Compilation and analysis of primary historical and bibliographic sources, in relation to the population of Alhama and its territory, with special attention to the Tajos. The written references offer us relevant data and descriptions about the history, geographical location, topographic implantation, heritage, economy and, above all, the power of fascination that the natural and landscape environment of the Tajos has had on the travelers who, throughout the centuries, have visited the city. At a graphic level, the cartographies, planimetries, lithographs and historical photographs allow us to understand and support the analysis of written documents.

2. Fieldwork consisting of walking tours along the historical and contemporary trails that run through the Tajos de Alhama and the formerly flooded area of the Marchán River for their recognition, as well as to register ditches, mills, aqueducts, bridges and other patrimonial elements that survive peppered in this natural setting (Figure 5).

3. Specific field work for the photographic and planimetric survey of the mills and their surroundings. The photographic documentation has been essential to record the state of conservation of each mill and the possible recovery and conservation actions from sustainability, analyzing in each case the current regulations (Figure 6).

4. Laboratory work for the photogrammetric reconstruction of the Fábrica de Harinas la Purísima integrated into its surroundings, as an example to follow of heritage recovery and enhancement, currently used as an interpretation center and museum. 


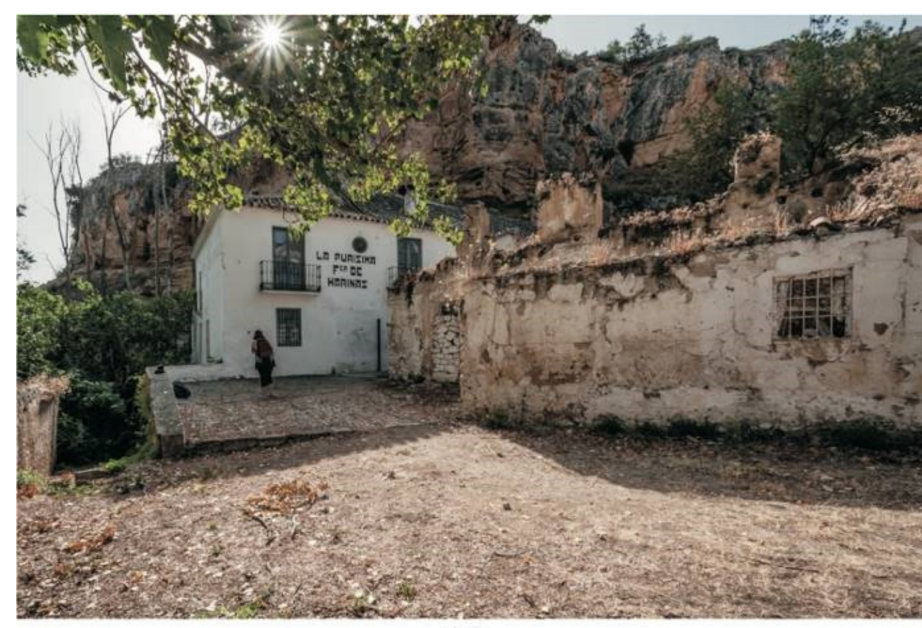

(a)

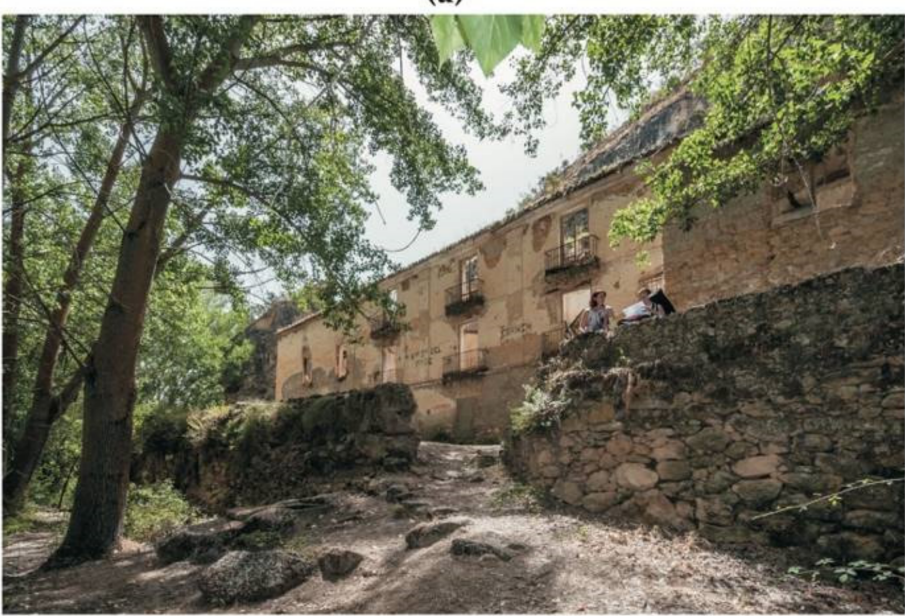

(b)

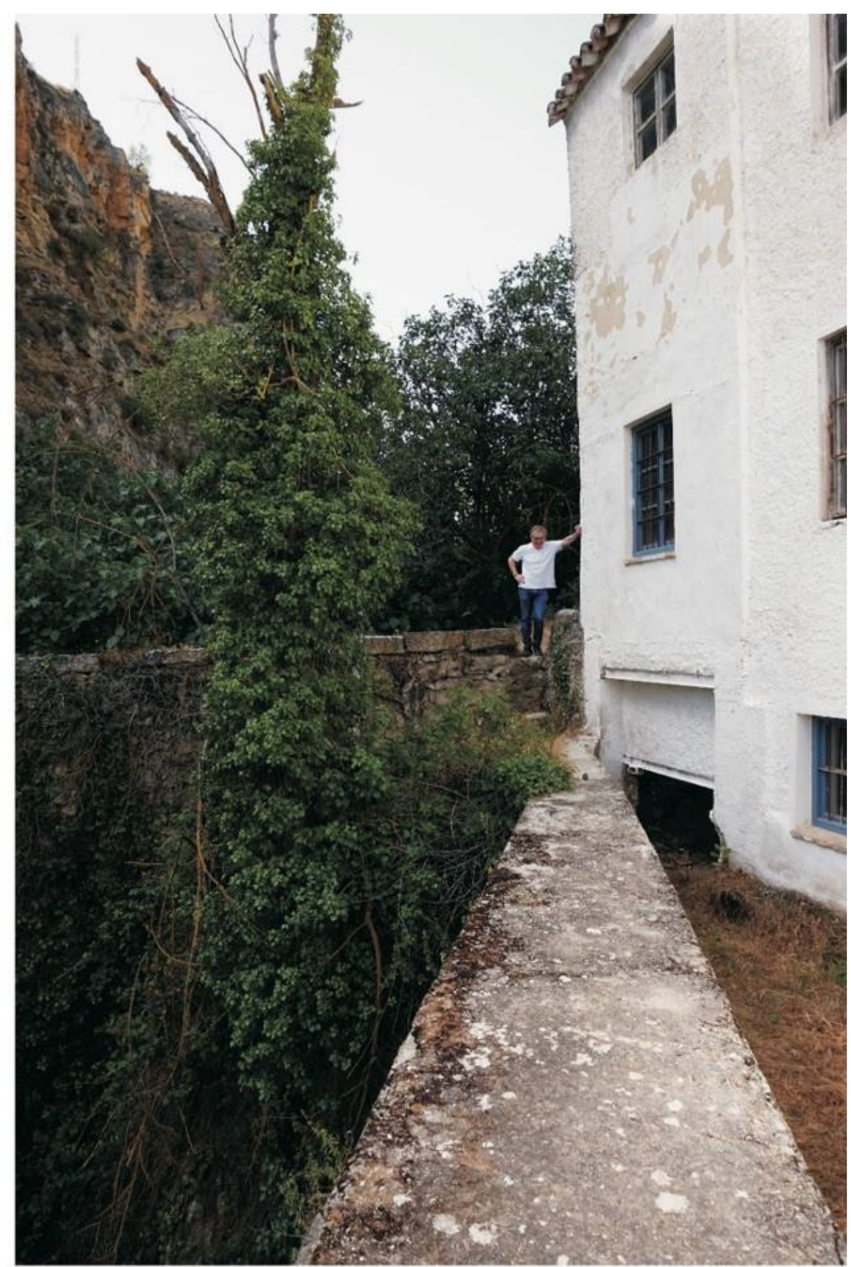

(c)

Figure 5. Photographs of the registration of the elements in the walking tours: (a) access path to the Fábrica de Harinas la Purísima (J.G.M.-S.); (b) Fábrica de Harinas Nuestra Señora del Carmen from the Alhama River (J.G.M.-S.); (c) facade of the Fábrica de Harinas la Purísima towards the Alhama River (M.d.C.V.-L.).

The material used for the photographic record of the walking tours and exteriors and interiors of the mills has been a Nikon D90 camera and AF-S DX Zoom-Nikkor 10-24 mm $\mathrm{f} / 3.5-4.5 \mathrm{G}$ ED lens. It is a digital SLR camera with 12.9 megapixel $\left(23.6 \times 15.8 \mathrm{~mm}^{2}\right) \mathrm{CMOS}$ image sensor and integrated dust reduction system. The lens is an ultrawide-angle that has a 10-24 mm focal length and maximum aperture F3.5. The wide $10 \mathrm{~mm}$ end allows a $109^{\circ}$ angle of view to be covered, almost a fisheye, providing spectacular perspectives with minimal distortion. This lens is ideal for capturing photographs of natural landscapes, architecture and interiors, capable of focusing as low as $24 \mathrm{~mm}$. In photographs where it has been necessary to slow the shutter speed, the camera has been placed on the Benro IT 15 tripod and a Nikon wireless shutter has been used to prevent any slight camera shake.

The aerial images of the surrounding of the mills have been taken with the ultralight DJI Mini 2 Drone, takeoff weight being less than $249 \mathrm{~g}$; it incorporates a camera with a 1/2.3" 12 Megapixel CMOS image sensor. The camera has an $83^{\circ} \mathrm{FOV}, 24 \mathrm{~mm}$ equivalent, fixedaperture F2.8 lens and an ISO range of 100-3200. It fits into a small but very effective 3-axil gimbal (tilt, roll, pan), with a tilt controllable range $-90^{\circ}$ to $+20^{\circ}$. The remote controller has a signal transmission range of $3 \mathrm{~km}$ in urban landscape with strong interference and $6 \mathrm{~km}$ in suburban landscape, with some competing signal, as is the case of the Tajos. It allows the control of the aircraft, the tilting of the gimbal, the taking of photographs and modes and exposure time $[19,20]$. 


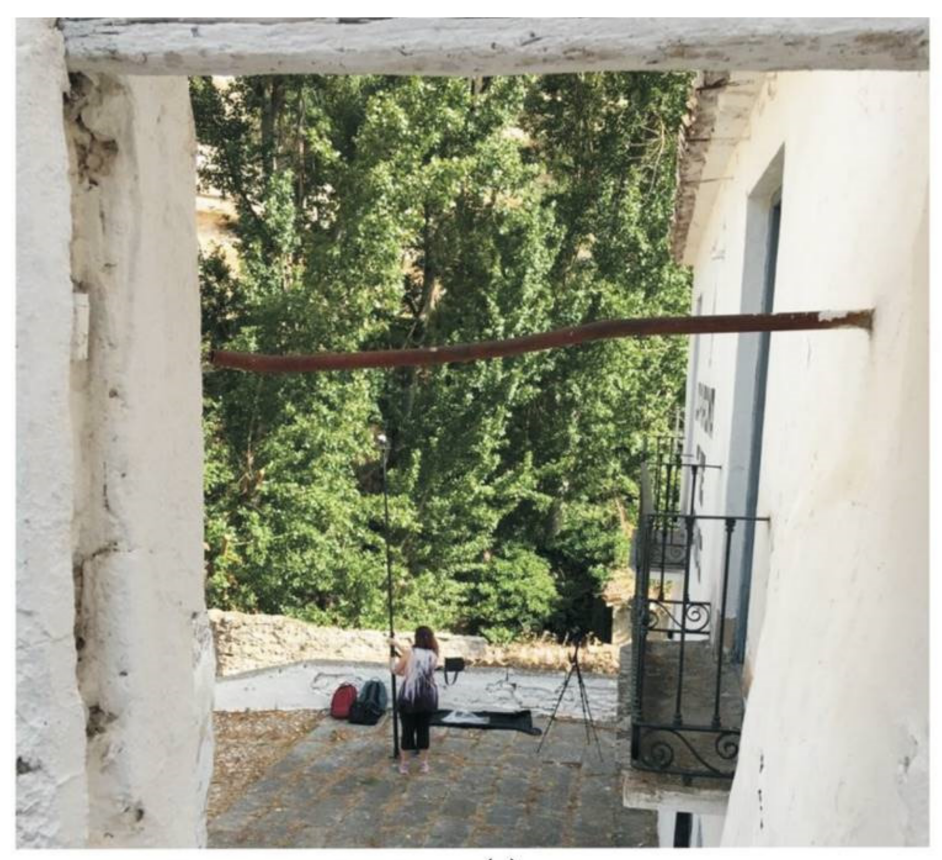

(a)

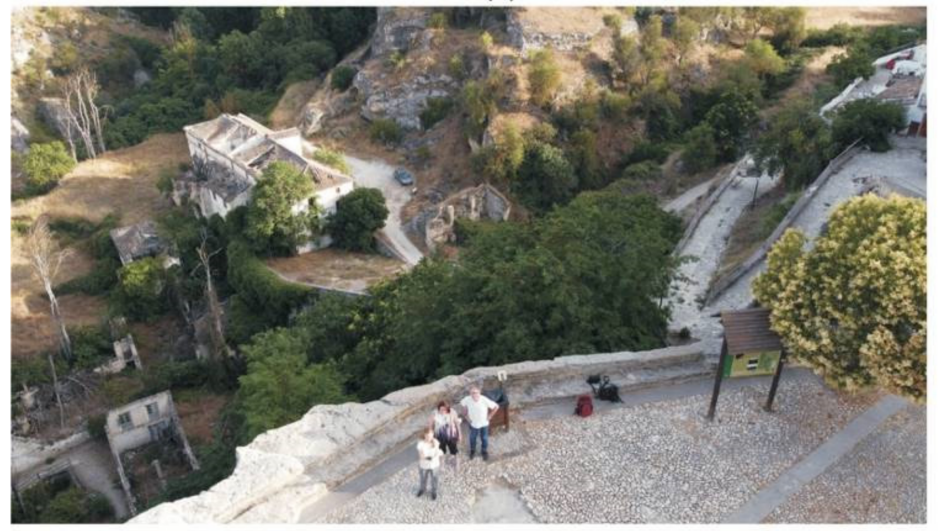

(b)

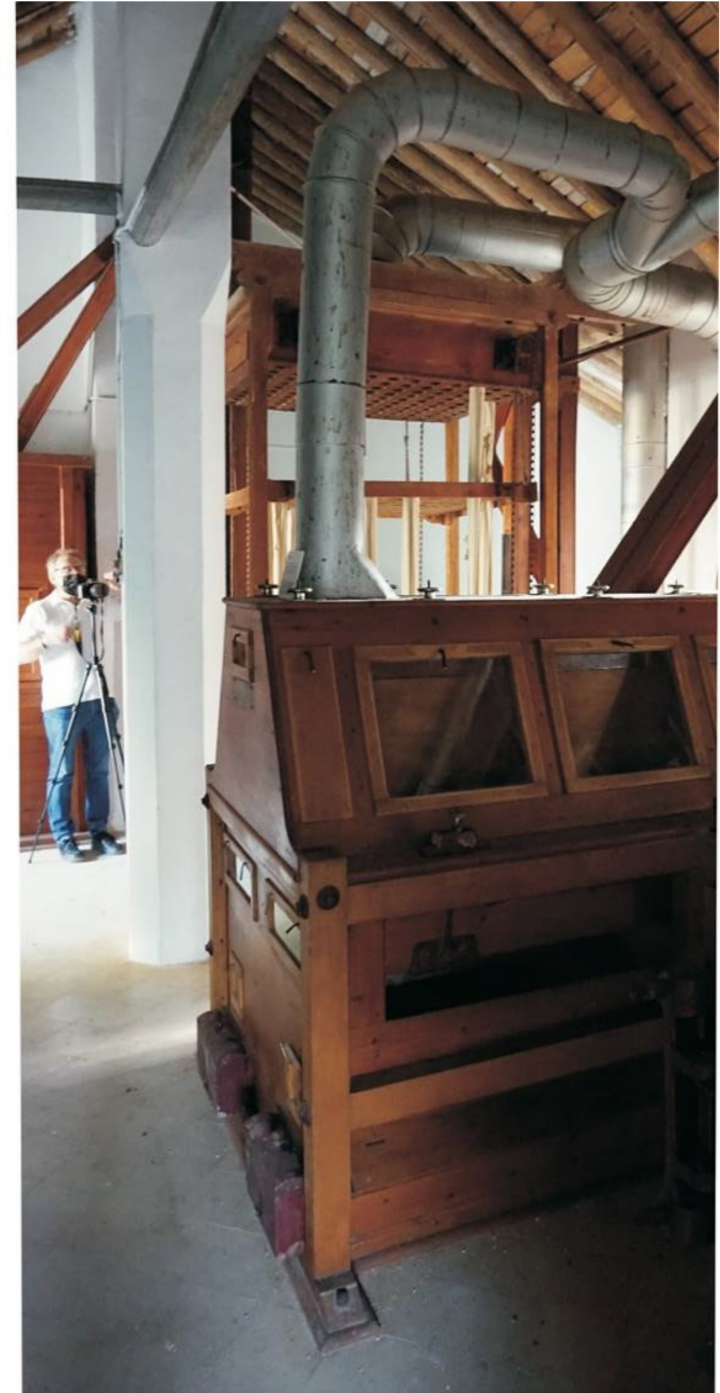

(c)

Figure 6. Photographs of the field work for the photographic and photogrammetric record: (a) photographic equipment and pole (J.G.M.-S., M.d.C.V.-L. and C.R.-M.); (b) image taken with DJI Mini 2 Drone (M.d.C.V.-L.); (c) Nikon D90 camera and tripod inside the Fábrica de Harinas la Purísima (J.G.M.-S.).

The instruments used in the photogrammetric survey of the Tajos area, which includes the interpretation center of the mill and house of the Fábrica de Harinas la Purísima and the 16th century aqueduct, have been a Sony Alpha 5000 camera and an extensible pole up to $10 \mathrm{~m}$.

Sony Alpha 5000 camera stands out for its low weight compared to its high quality. It has a 20.1 Megapixel APS-C $(23.2 \times 15.4 \mathrm{~mm})$ image sensor. The retractable lens with electronic zoom has a 16-50 $\mathrm{mm}$ focal length and maximum aperture F3.5. Wireless sharing with Wi-Fi connectivity lets the camera be used with the mobile as remote-control thanks to Imagine Edge Mobile App when the camera is hung on a pole.

The pole on which the camera was placed to obtain the photos in height is Photomast MK $210 \mathrm{~m}$, with a light and strong high density carbon fiber inner core, a stable mast and a flexible lightweight rubber base, which facilitated its positioning in the different points of uneven terrain (Figure 7 and Table 1). 


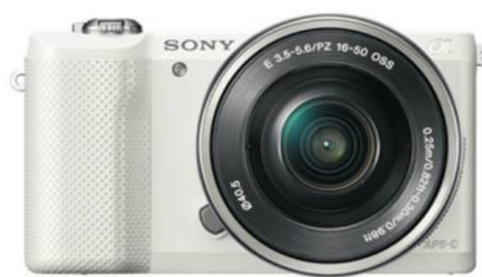

(a)

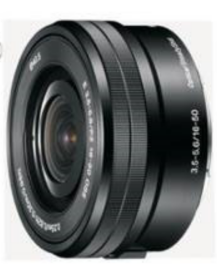

Figure 7. Photographic equipment: (a) Sony Alpha 5000 camera; (b) Nikon D90 camera lens: AF-S DX Zoom-Nikkor 10-24

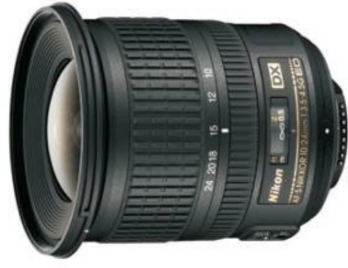

(b)

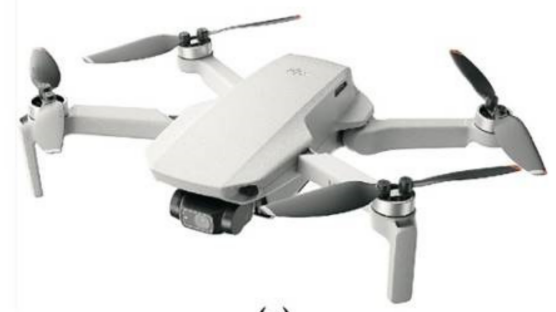

(c) $\mathrm{mm} \mathrm{f/3.5-4.5G} \mathrm{ED;} \mathrm{(c)} \mathrm{DJI} \mathrm{Mini} 2$ Drone.

Table 1. Features of the cameras used in this research.

\begin{tabular}{cccc}
\hline Type of Camera & Sensor & Focal Length & F-Value \\
\hline \multirow{2}{*}{ Sony Alpha 5000 } & APS-C $(23.2 \times 15.4 \mathrm{~mm})$ & $16-50 \mathrm{~mm}$ & $\mathrm{f} / 3.5$ \\
& $20.1 \mathrm{MP}$ & \\
\hline \multirow{2}{*}{ Nikon D90 } & AF-S DX $(23.6 \times 15.8 \mathrm{~mm})$ & $10-24 \mathrm{~mm}$ & $\mathrm{f} / 3.5$ \\
& $12.9 \mathrm{MP}$ & \\
\multirow{2}{*}{ DJI Mini 2 Drone } & $1 / 2.3^{\prime \prime}$ & \\
& $12 \mathrm{MP}$ & \\
\hline
\end{tabular}

The software used for the cartographic survey of the territorial landscape of water of the Tajos de Alhama and the mills have been: AutoCAD 2020 for 3D modeling, 3DStudio 2022 for the realization of the renders and Adobe Photoshop CS5 for the composition of the views (plan and sections).

We used the software Agisoft PhotoScan to obtain the 3D model and the orthorectified plan as a result of the photogrammetric process [21].

\section{Results}

This section has been divided by four subheadings as a direct result of the methodology carried out.

\subsection{The historical landscape of Alhama and Its Tajos}

Deep knowledge of the history of a heritage asset (landscape, architectural, ethnological, etc.) is an unavoidable step prior to its rehabilitation. As a result of the compilation and analysis of the historical sources, we can conclude that the oldest human footprint found in Alhama is from the Neolithic age and is represented by three caves (Figure 8), two of them located on the Cerro de la Mesa del Baño, next to the Alhama River and the Arab baths, and the other in the Tajos next to the urban nucleus (Figure 9). 


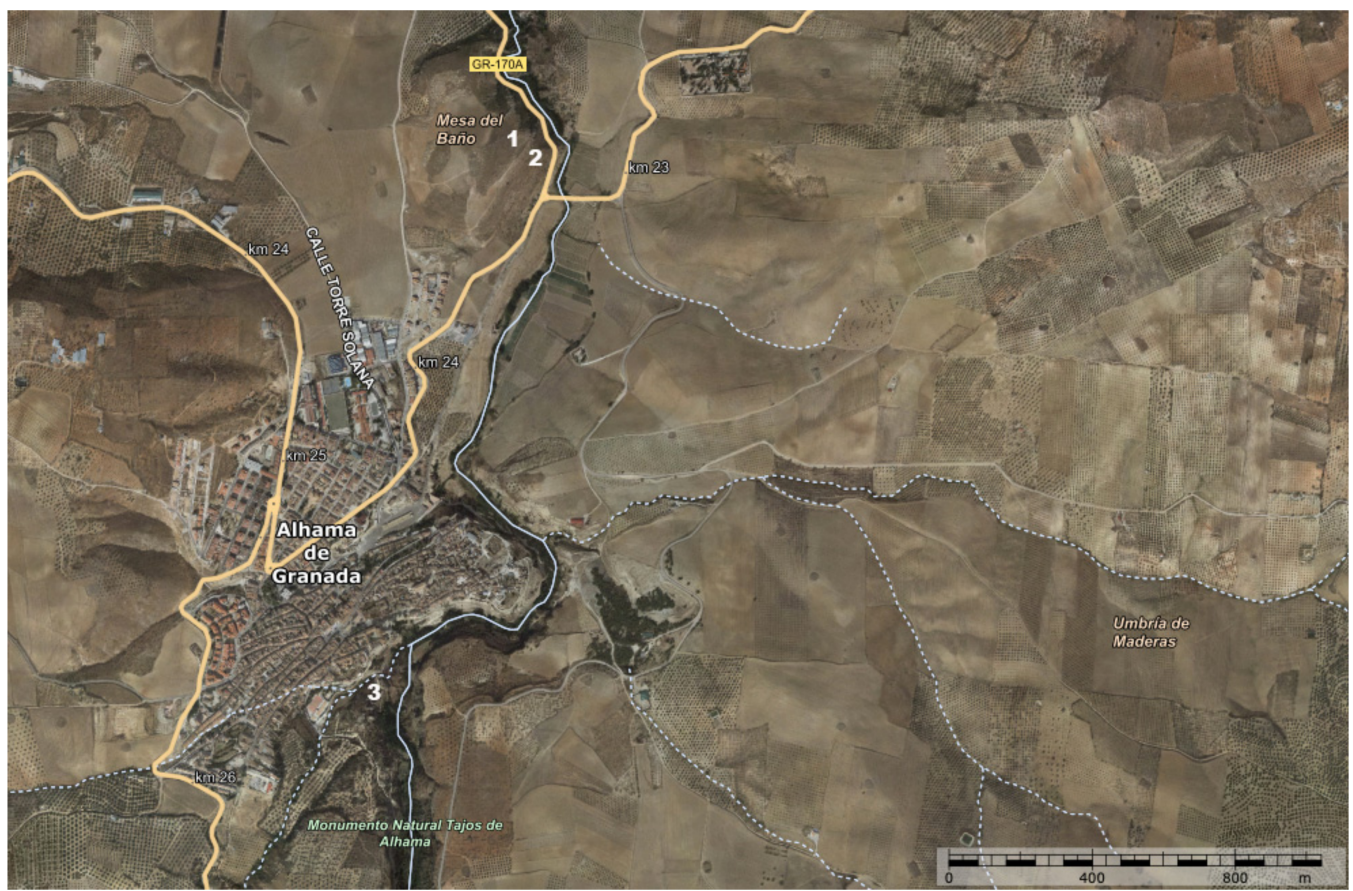

Figure 8. Location of the three Neolithic caves of Alhama de Granada: 1. Cueva de la Mujer; 2. Cueva del Agua; 3. Cueva de los Molinos. Base plan of the Instituto Geográfico Nacional.

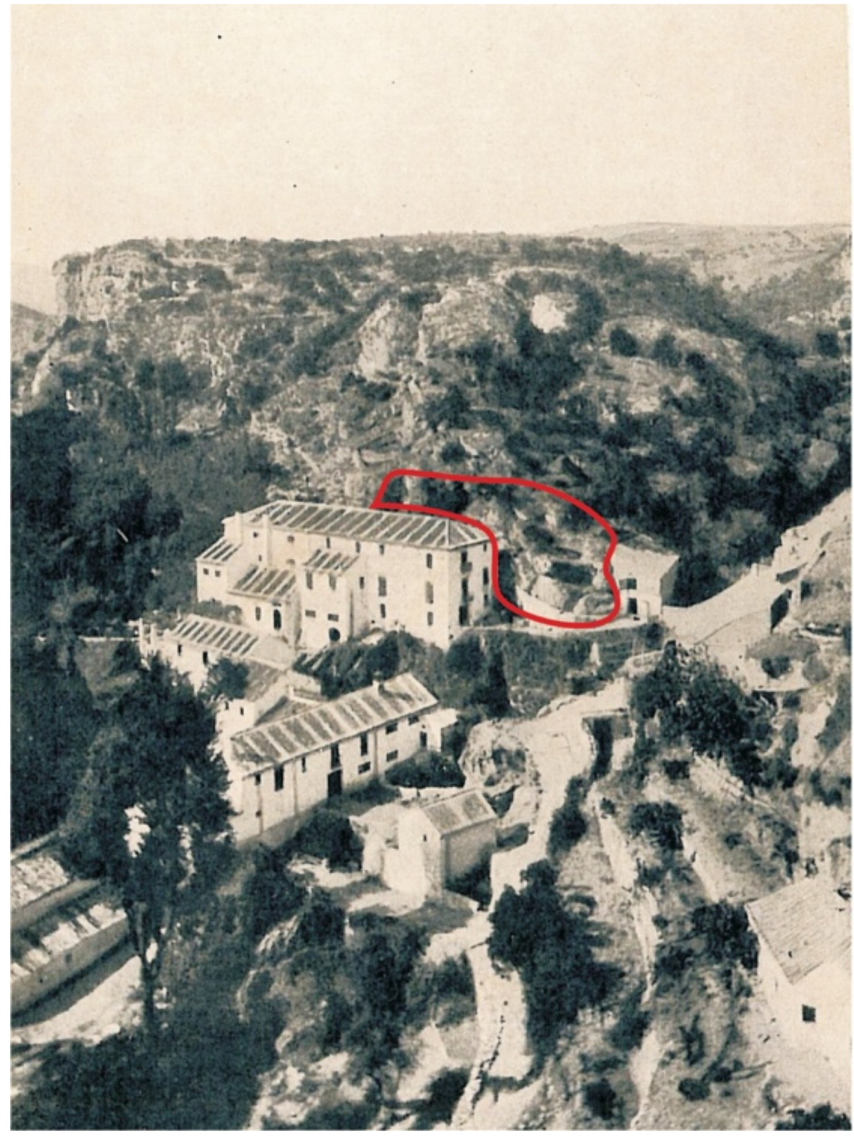

(a)

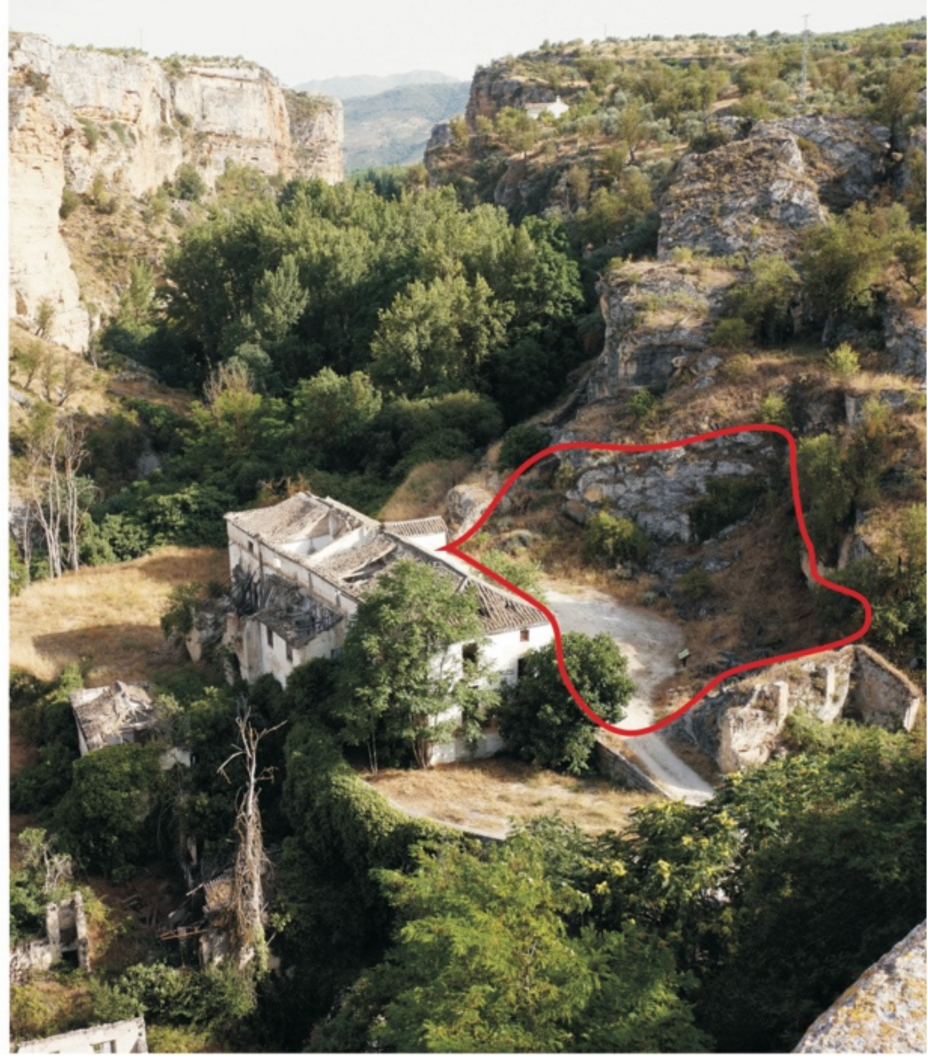

(b)

Figure 9. (a) Photograph from the end of the 19th century where the promontory of the Cueva de los Molinos was still (www.fcalapurisima.com, accessed on 15 April 2021); (b) photograph taken on 9 July 2021 (M.d.C.V.-L.). 
The caves called la Mujer and el Agua were discovered by Macpherson in 1869, who believed that it was a single cave with two entrances [22]. Years later, the caves were excavated by Manuel Gómez-Moreno González, between 1872 and 1875, and by his son Manuel Gómez-Moreno Martínez, in 1894 [23]. The archaeological work continued in 1957 and 1958, directed by professors Pellicer and García Sánchez [24], thanks to which valuable ceramic materials and human remains were extracted [25]. The third cave, called Los Molinos, is located on a slope of the Tajos de Alhama that leads from the town to the riverbed. It is behind the former Fábrica de Harinas San Francisco, within the area called El Cañón. The first material discoveries of this cave were discovered in 1968 by chance, during works to flatten the access road to the town [26]. Unfortunately, this slope had been used as a quarry until, in 1974, one of the holes placed in the upper part exploded and a crack was discovered in which human remains and a piece of furniture were found. At the same time, the cave was almost completely destroyed.

The testimonies of Plinio the Elder and Claudio Ptolemy make us direct the origin of Alhama to the ancient city called Artigi Iuliensis, according to Plinio, and Artigis, according to Ptolemy $[27,28]$, inhabited by the Turduli.

Alhama reached all its splendor in the Nasrid period, in which it changed its name from Artigis to Alhama and was presented as a strategic city, strongly walled, which was also helped by the high vertical walls of the natural accident of the Tajos, which protected it against possible invaders. At the western end of the medina, its strong castle was located on top of a hill, thus described by the traveler Jerónimo Münzer in his journey of 1494 [29] (p. 113). The walls had two main gates, Granada and Málaga, as well as two secondary gates and several wickets [8] (p. 46).

The taking of Alhama by Christian troops on 28 February 1482 under the command of a group of Castilian and Andalusian nobles has been widely narrated and praised by literature [30-34]. We even find it carved in relief in the choir of the Cathedral of Toledo, the work of the sculptor Rodrigo Alemán at the end of the 15th century [35]. The truth is that it had a great repercussion, marking the beginning of the end of the Muslims in the Iberian Peninsula, for ten years later Granada would fall at the hands of the Catholic Monarchs on 2 January 1492.

The views of Alhama drawn by Joris Hoefnagel in 1564 and Anton van der Wyngaerde in 1567 offer us a graphic imprint of the city and its surroundings of incalculable value. The one at Hoefnagel, included in the Civitates Orbis Terrarum [36,37], places the thermal baths in the foreground. In the central part of the image, he draws the city of Alhama in which the church of the Encarnación takes on a special role, dominating the rest of the hamlet surrounded by Muslim walls, thicker in the western part. At the landscape level, he shows the rolling hills that characterize the landscape of the region and as a backdrop to the Sierras de Tejada, Almijara and Alhama. However, due to the chosen point of view, the steepest cutting Tajos located to the east have been hidden by the hamlet, showing only their northern and western parts (Figure 10). This is not the case in Wyngaerde's view [38-40], in which we are fortunate enough to glimpse the east Tajos and compare them with the current state, verifying the detachment of some rocks after the 1884 earthquake. Within the city, Wyngaerde also highlights the unmistakable urban landmark of the Church of the Encarnación, in addition to the Moorish Castle, along with an aqueduct. On the right, in the foreground, we can see the missing guard tower and, at its feet, the baths (Figure 11). 


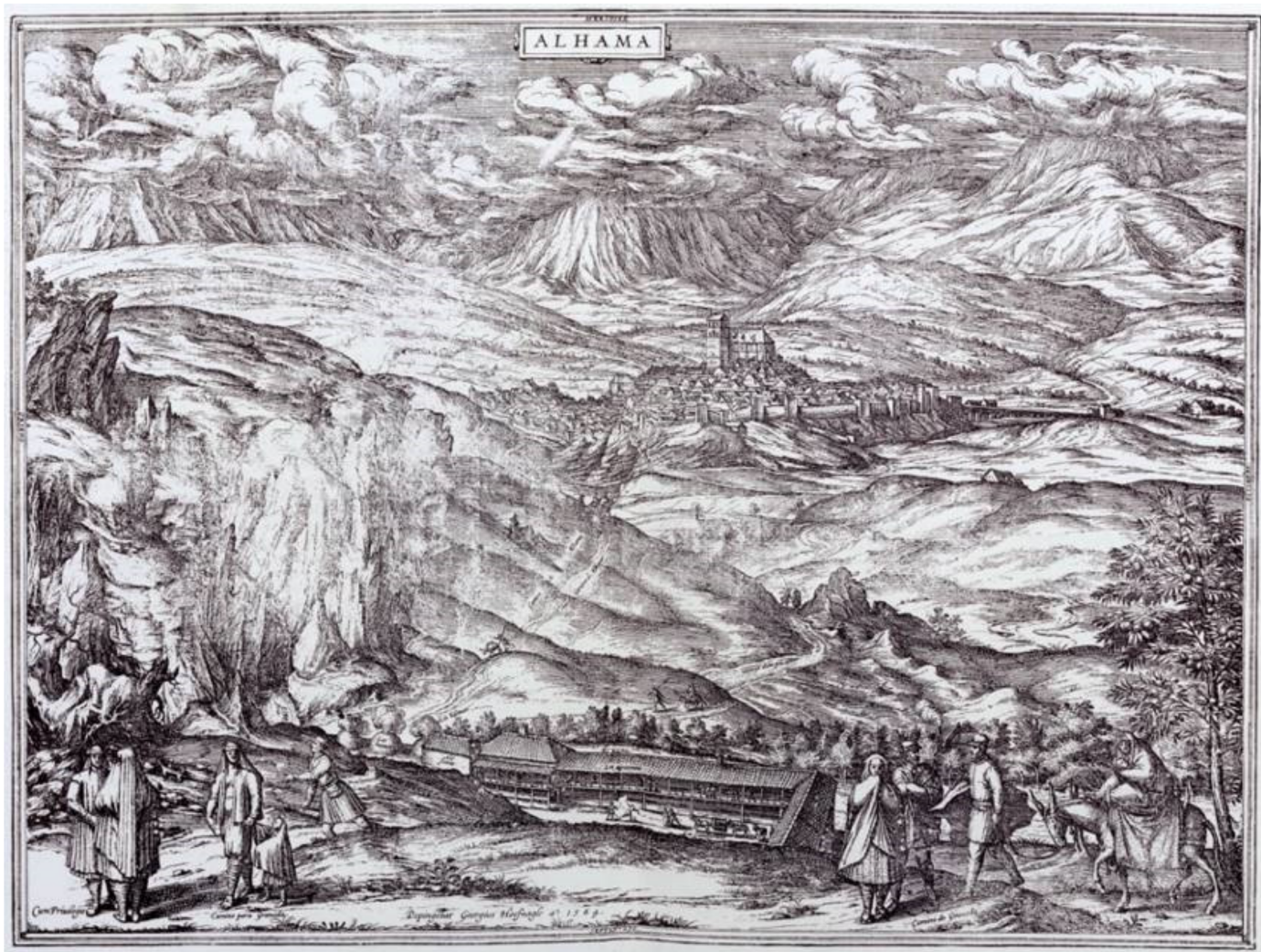

Figure 10. Alhama (Joris Hoefnagel, 1564).

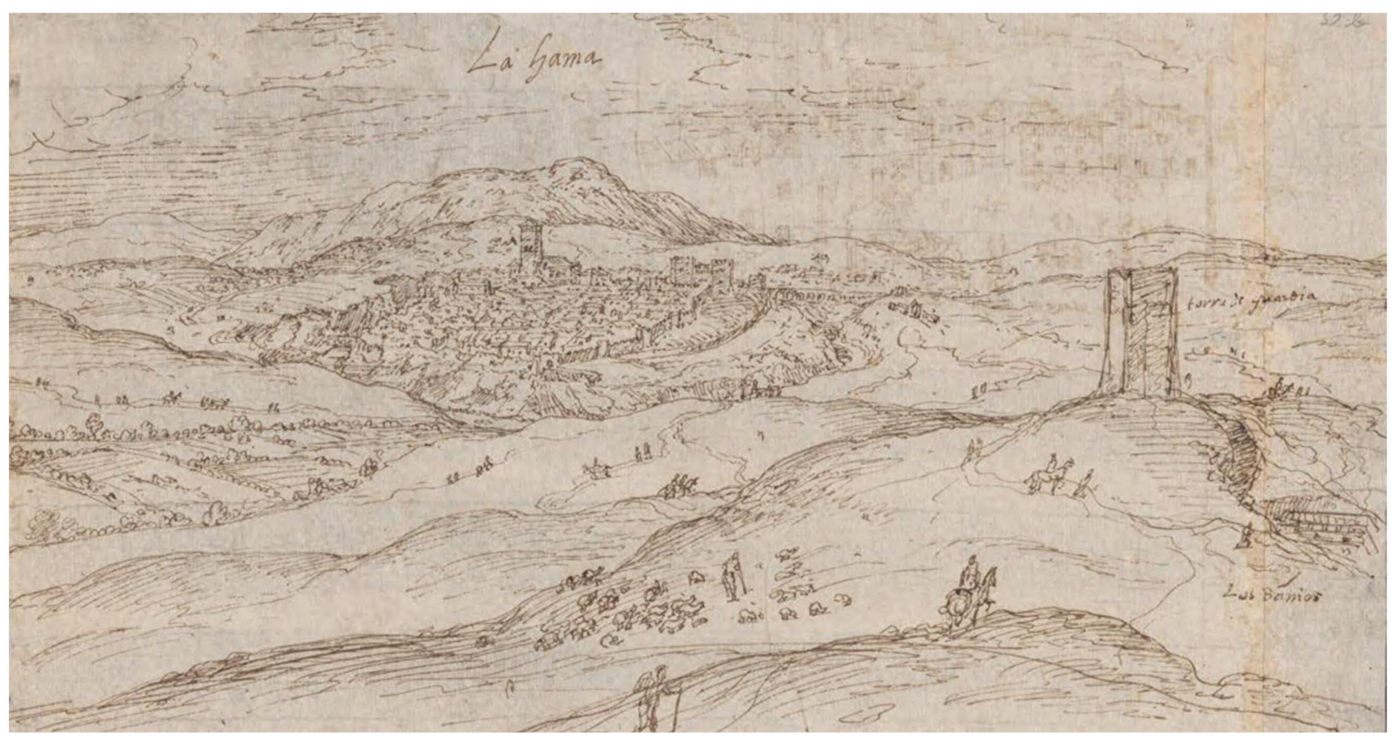

Figure 11. Alhama (Wyngaerde, 1567).

The maps of the first third of the seventeenth century, by Hondius [41] and Texeira [42], place Alhama among the most important towns of the time, belonging to the Kingdom of Granada (Figure 12). 


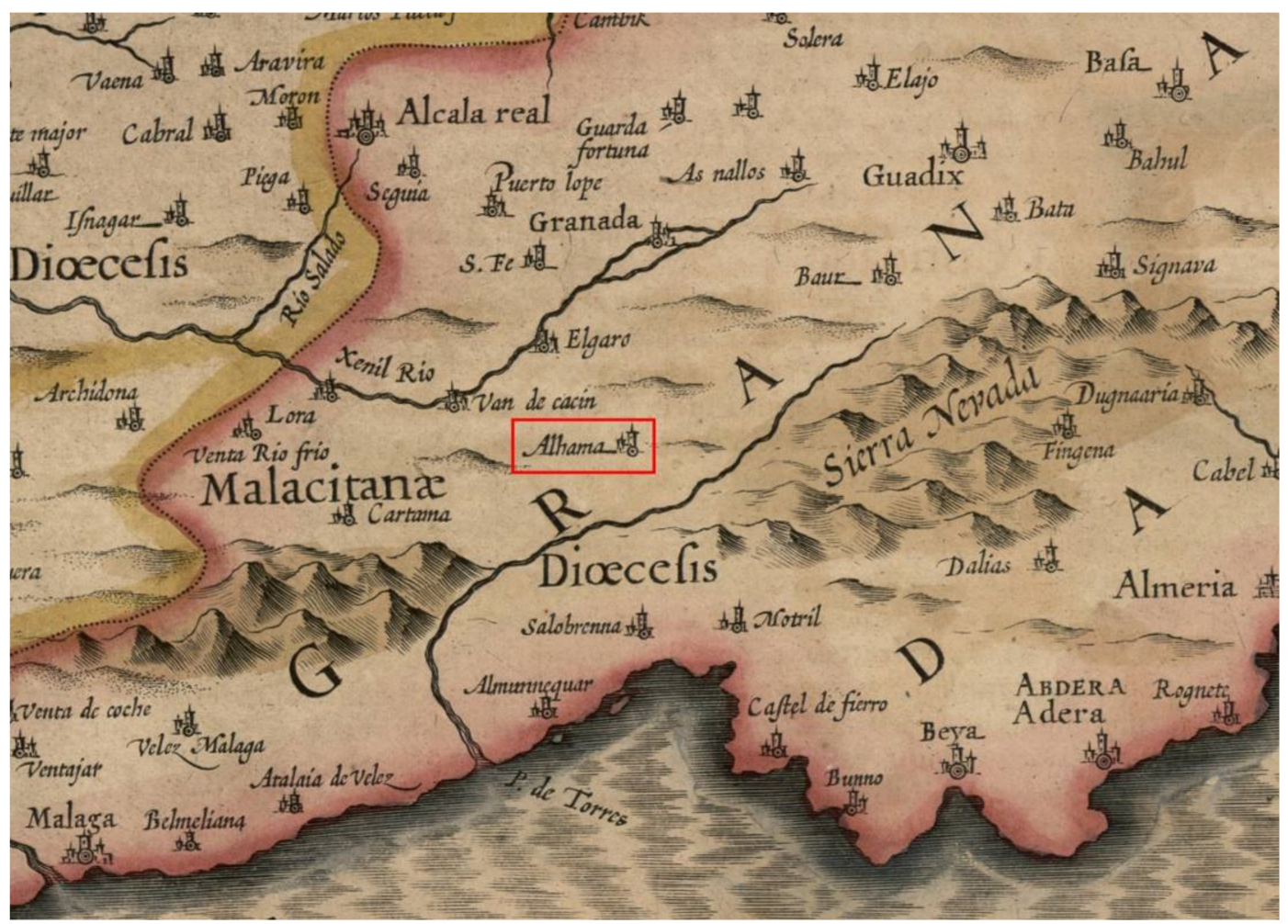

Figure 12. Alhama situada en el mapa Andaluziae nova descript. (I. Hondius), 1623 [41].

In 1787, the geologist and doctor Townsend arrived in Alhama, whose book A journey through Spain is the first that describes in detail the natural area of the Tajos and its relationship with the city: "Alhama is remarkable for situation, being almost surrounded by a precipice, from which you look down upon a river, at least two hundred feet below you. In this it is beautiful to see and hear numerous cascades, assuming various forms, all foaming among the rocks; and when they have spent their fury, gliding almost imperceptibly along in one continued stream. Thus situated, the city is accessible only from the west, where a castle, formerly reputed strong, but now going to decay, commands the entrance" [43] (p. 49). He also describes the agrarian landscape, with its wheat fields, and is interested in farming practices.

At the end of the 18th century, Antonio Ponz visited Alhama, whose region he affirms is abundant in grain harvest and highlights the aqueduct that carries water to the city. About its location and the Tajos, he writes: "Its situation is very high with respect to the river that they call Marchán, or Alhama, which is born about a league from the city, running through its eastern and northern part a very high almost perpendicular gorge, whose elevation is partly more than two hundred varas. It is frightening to look at it from the city, and on the other hand it is an object of amusement thanks the orchards, groves, mills, etc. that are discovered in that depth." (Translated by the authors, original text from [44] (p. 263)).

The North American Robert Semple arrived in Alhama in the spring of 1809 and was impressed by its location, the Tajos and the water mills: "Even by the light of the stars it was easy to discern the romantic situation of this town as we wound up the hill, and the ensuing morning enabled me to survey it more particularly. It is seated chiefly on a rocky height elevated more than three hundred feet above the level of a small stream which flows in the valley beneath, and is here called the Tajo, [ ... ]. The view from that part of the town overhanging the stream is particularly beautiful. The rock is here nearly perpendicular, and we see beneath our feet a charming valley bordered on each side by steep and romantic cliffs, the summits and hollows of which are covered with trees. At the bottom are several mills turned around by the rushing stream." [45] (p. 214).

Three of the English travelers who were in Alhama in the first third of the 19th century were William Jacob, Charles Scott and Richard Ford. Jacob arrived in January 1810 [46] and, 
after describing the abundant wheat fields, he noticed the location of the city surrounded on three sides by a river, which runs at great speed through the fissure of the impressive Tajos and successively moves eight mills to grind grain. Jacob also visited the main church and the castle, which he found in ruins. Scott visited Alhama in 1822, and the most remarkable part of the city was found at the bottom of the fissure, where there "are numerous picturesque water-mills; and, viewed from thence, Alhama furnishes an excellent subject for the painter" [47] (p. 224). In the early 1930s, Ford came to city, describing it as wild and picturesque and comparing it to Ronda, "perched on the edge of an awful rent in the hills round which the river Marchan sweeps. [ ... ] The view of the Tajo from the convent de San Diego, is striking. Below tears the foaming Marchan, winding though ravines and rocky pinnacles. The whole scene is made for the painter; on the ledges of the beetling cliffs are picturesque houses, with trellised vines and hanging gardens, while below boil water-mills and cascades." [48] (pp. 357,358).

The French traveler Théophile Gautier left us a memorable description on his visit to Alhama in 1840, when he poetically compared it to an eagle's nest perched on top of a steep rock and affirms that nothing was as picturesque as the sharp angles of the path that led to this hawk zone, bending into the cracks in the ground [49] (p. 287).

We have located two lithographs from this period, one of them drawn by Nicolas Chapuy in 1844, from the medieval road that led to Alhama from Malaga in the middle of the Marchán River valley that runs between the Tajos (Figure 13). The other lithograph, dated circa 1840, is attributed to Gautier. It offers us a spectacular view from one of the natural viewpoints of the city, on the edge of one of the vertical walls of the Tajos. Down at the bottom of the valley to the right of the river, we discover the mill of Nuestra Señora del Carmen, which was accessed through a bridge where we see some villagers walking. In the viewpoint, there are several characters dressed in period clothes, including hats (Figure 14).

In 1851, it was a woman writer and traveler, Lady Louisa Tenison, who offers us a description of this landscape: "The rocks, which form the sides of the gorge, rise almost perpendicularly from the bed of the river gliding at their feet; while above their beetling crest appears an uneven line of houses, built on the very verge of the precipice" [50] (p. 37).

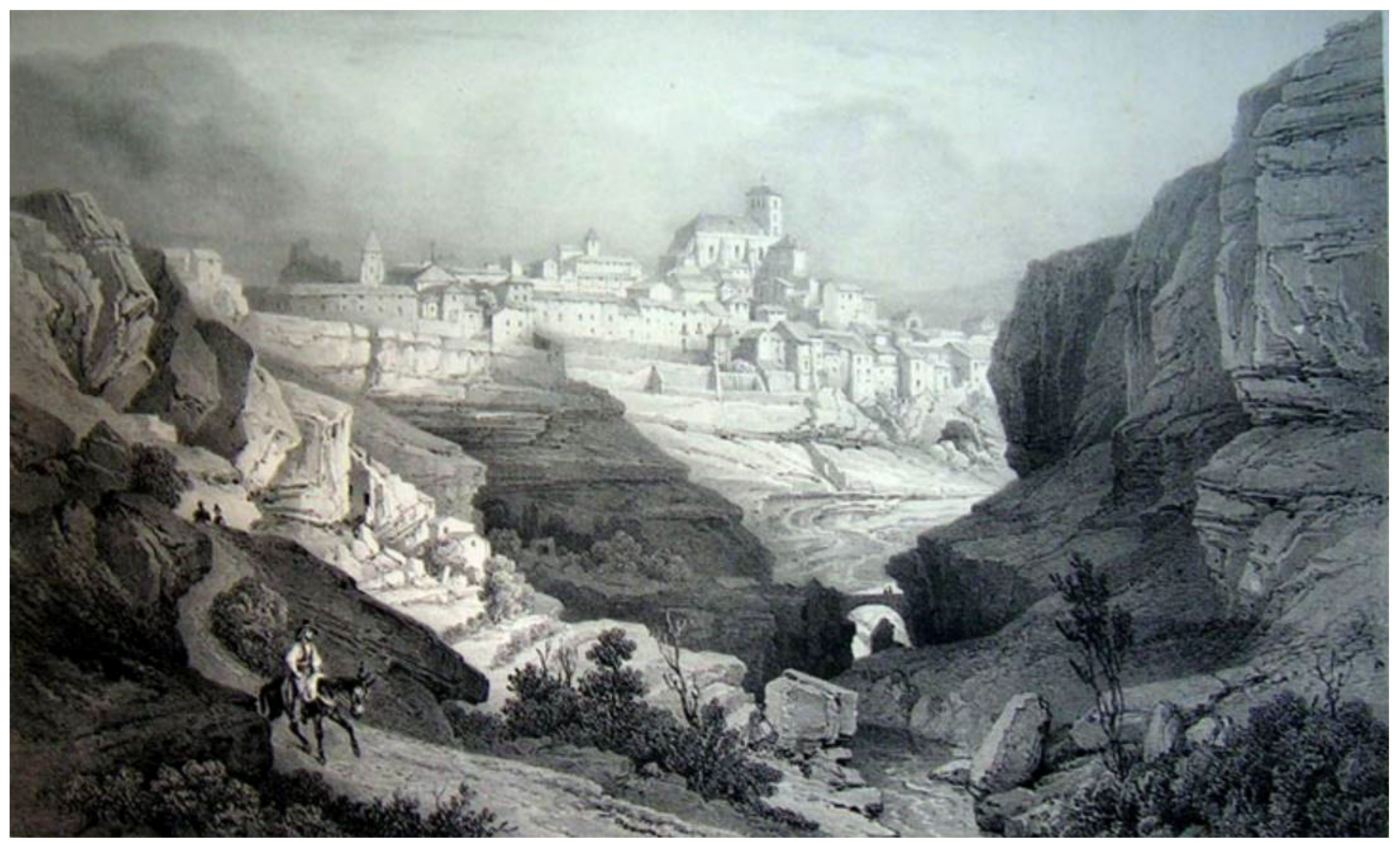

Figure 13. Lithograph of Alhama, 1844 (N. Chapuy). 


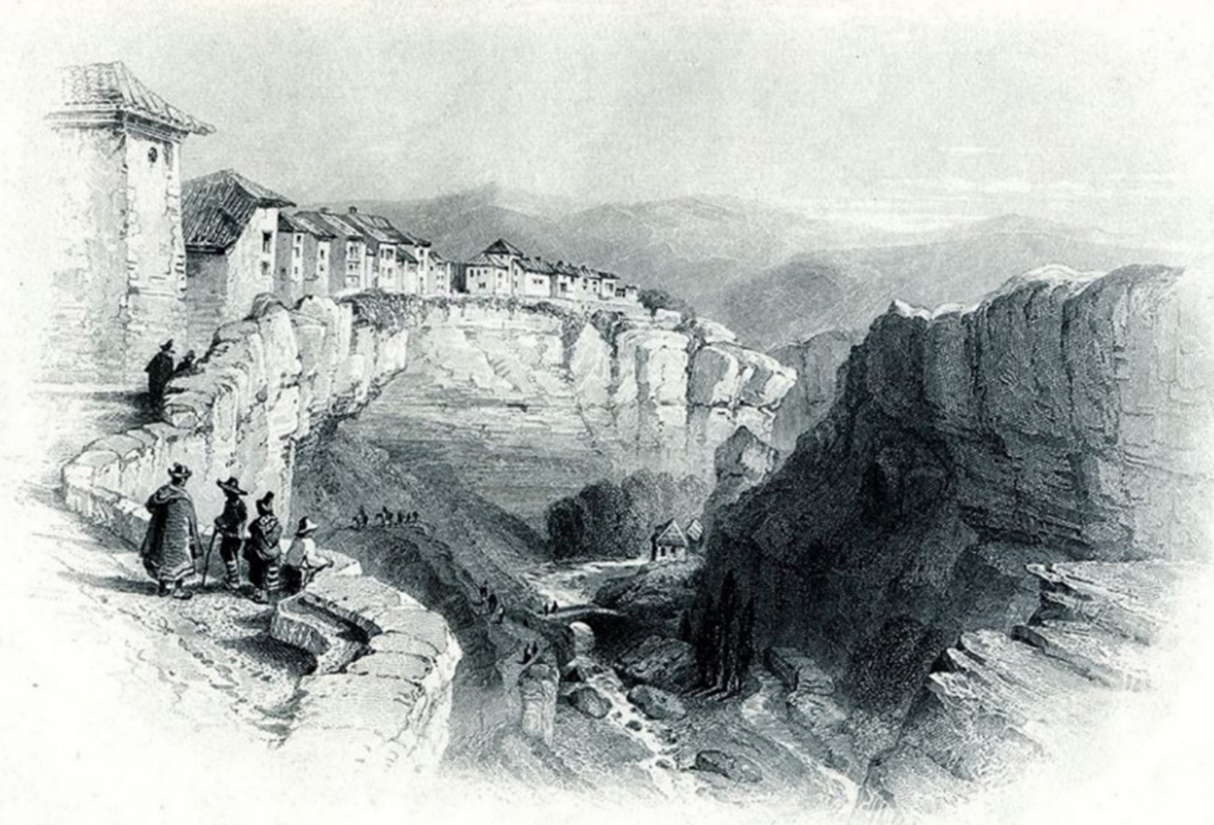

Figure 14. Lithograph of Alhama, circa 1840 (attributed to Gautier).

Years later, the consequences of the great earthquake that occurred on Christmas Day 1884 in Alhama were devastating [51-54], causing the collapse of numerous houses, serious damage to the historical heritage, the detachment of the houses on the edges of the Tajos and the breaking of the irrigation canals, producing the paralysis of all the mills (Figure 15). The human losses were very high in Alhama and its region; more than 1200 people lost their lives [55]. As a result of the earthquakes, three new neighborhoods were built in the city: Imparcial, Buenos Aires and La Joya [56] (p. 53).

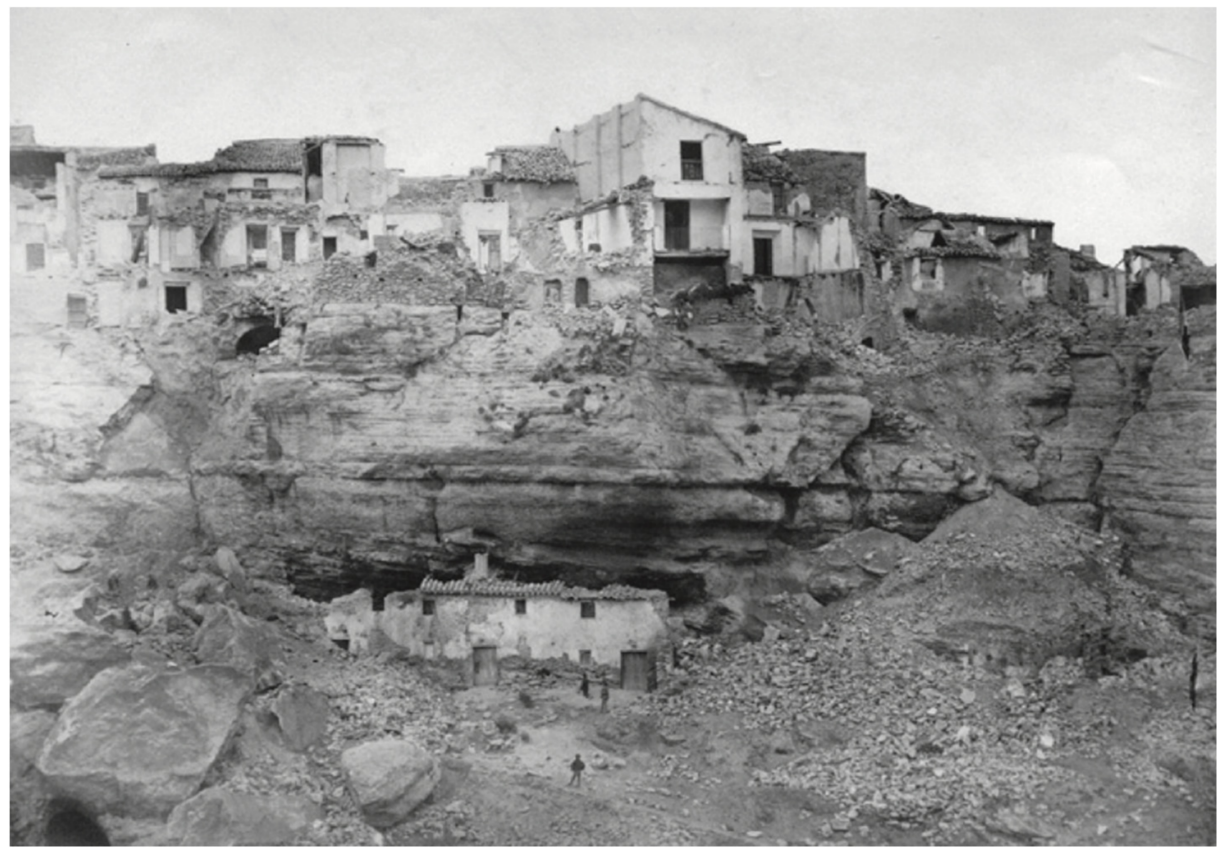

Figure 15. Photograph taken after the 1884 earthquake of a sunken house on the edge of the Tajos [54].

At present, traces of this tremendous earthquake still survive in the Tajos, appreciable in the detachment of large rock cliffs. 


\subsection{The Landscape of Water}

As a result of our walking tours through the Tajos de Alhama and the formerly flooded area of the Marchán River, we have registered the most relevant geographical and heritage elements related to this cultural landscape of water: ditches, irrigation canals, mills, reservoirs, etc. (Figure 16).

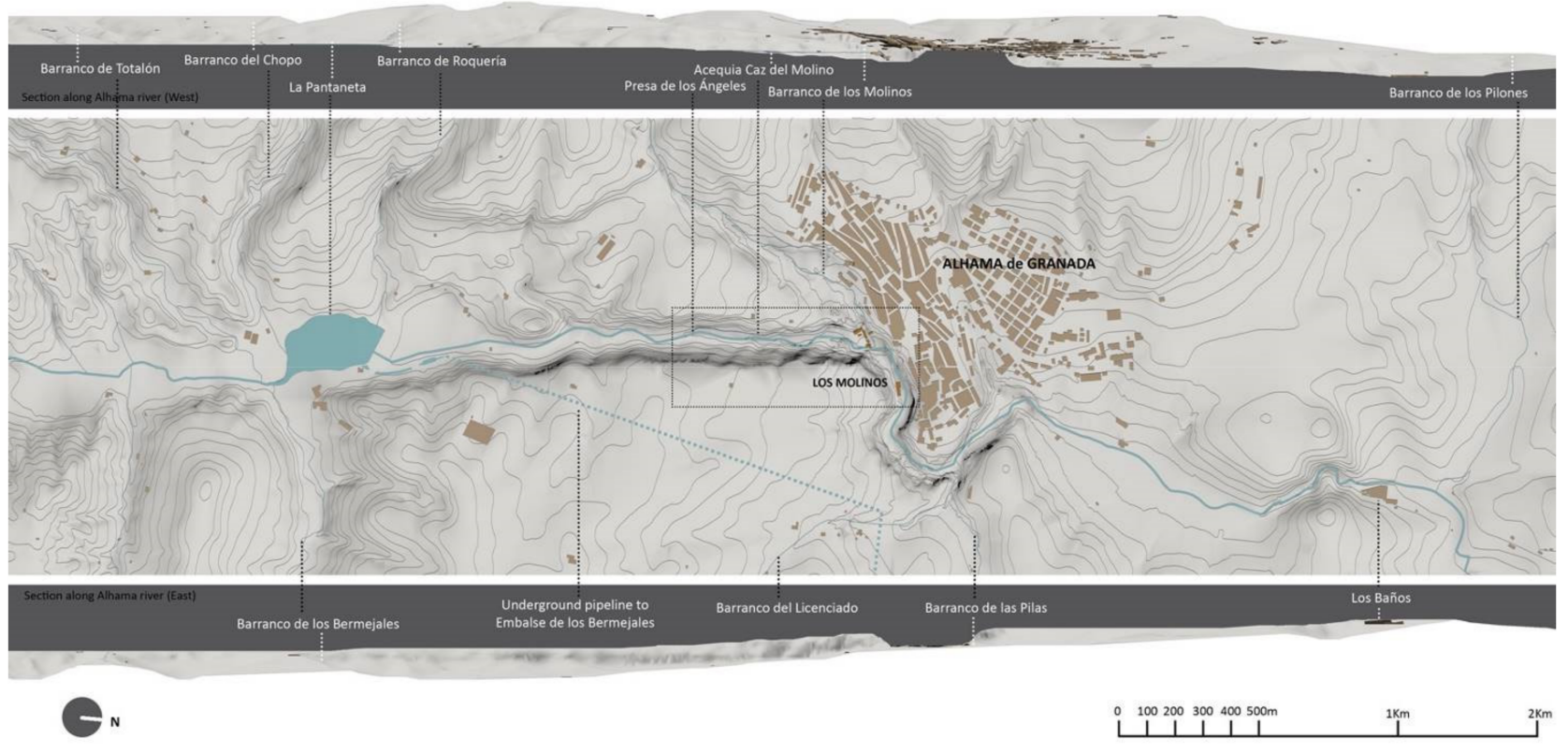

Figure 16. Landscape of water of the territorial area of the Tajos de Alhama: plan and sections along the Marchán River (C.R.-M.).

Our journey through this landscape linked to water begins at the Pantaneta reservoir. It is a relatively recent artificial intervention, from the middle of the last century, carried out for the accumulation and regulation of the water of the Marchán River that flows naturally until it reaches it. Although of artificial origin, little by little, it has been surprisingly integrated into nature, becoming an authentic wetland of great ecological, economic, cultural and social value, being included in the Inventario de Humedales of Andalusia in 2010 [57].

Since 1970, the Marchán Riverbed has been seriously affected after the completion of the canal works that the Confederación Hidrográfica del Guadalquivir decided to undertake for the transfer of water from the Pantaneta to the Bermejales Reservoir. This resulted in a notable decrease in downstream waters, which accelerated the closure of the water mills and produced a notable decrease in the quantity and quality of the water that flowed through the Tajos as it passed through Alhama, generating great controversy [58,59].

The ditches or irrigation canals are also part of this landscape, highlighting the main ditch called Caz del Molino. It is an artificial construction that diverted part of the water of the Marchán River to irrigate the crops and move the mechanical devices of the mills. This canal has its connection to the Presa de los Ángeles at the height of the hermitage of the same name. It took advantage of the existing unevenness to gain strength and lead, almost parallel to the Marchán River, the water that served in the past to move the five mills located in the Tajos until it emptied, after the last mill, into the river. Throughout its route, the canal has a variable section, channelized by large stones or naturally taking advantage of the rocky formation of the terrain. At present, this ditch only continues to transport water to irrigate some orchards in the fragment between its derivation in the Presa de los Ángeles and just before reaching the mill of the Fábrica de Harinas San Francisco.

The fragment of the ditch that fed the five mills was left in disuse after the closure of the factories, although, fortunately, there are still vestiges, such as aqueducts, water 
gates and sluice, to regulate the passage of water and overflows of the excess water to the Marchán River, such as the existing one in the Fábrica de Harinas la Purísima.

In this landscape of water, linked to the external image of the city, we find unique values and landscape resources, collected in the Catálogo de Paisajes de la provincia de Granada [60]:

- Scenic, aesthetic and sensorial values: abundance of viewpoints that allow the contemplation of the diversity of colors and textures that seasonal changes provide in crops, poplar groves, bushes, etc. (Figure 17).

- Natural and ecological values: the deep squeezing way of the Marchán River runs through natural gorges, in which a rich ecosystem of vegetation and fauna has been created (Figure 18).

- Historical and heritage values: the settlement of Alhama on a promontory protected by the cliffs, formerly surrounded by walls and with a Muslim castle.

- Symbolic and identity values: Alhama was a key point in the Christian conquest and was an obligatory step on the historic road between Granada and Malaga.
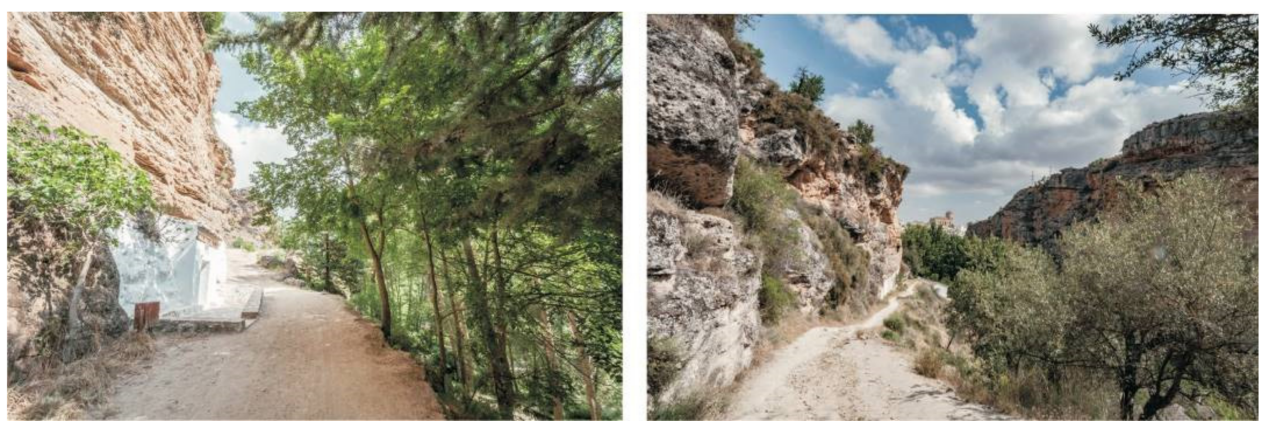

Figure 17. Medieval road between the Tajos, access to Alhama from Malaga (J. G.M.-S.).
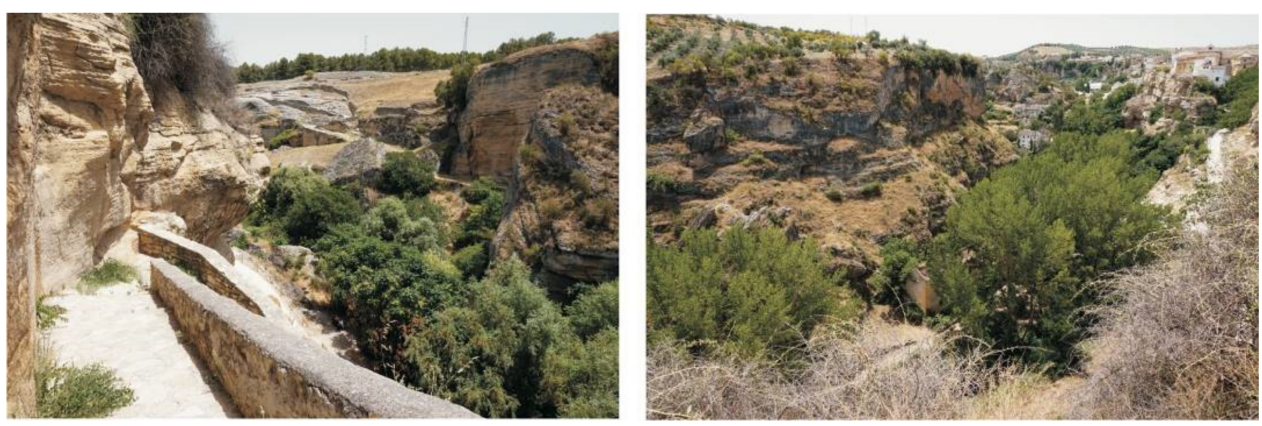

Figure 18. Way down to the Tajos, near the Nuestra Señora del Carmen mill (M.d.C.V.-L.).

\subsection{Mills Catalog}

This catalog has been prepared to serve as an instrument of knowledge and recovery of the industrial and ethnological heritage represented by the five water mills located in the Tajos of Alhama River. It is a catalog designed for the sustainability of this natural monument, threatened by the abandonment and ruin of a heritage that is part of it and must be protected, valued and safeguarded through its rehabilitation with compatible uses.

Each card of the catalog consists of the following epigraphs: identification, location, brief description, constructive characteristics, state of conservation, actual use, conservation proposals, enhancement and compatible uses. Photographic documentation of each mill has also been included. Below, we include as an example the catalog card of the Fábrica de Harinas la Purísima:

- Identification: Fábrica de Harinas la Purísima.

- Location: Paraje de los Molinos, Alhama de Granada, Spain. 
- Brief description: Reference to the industrial heritage of the municipality of Alhama and of the flour mills of the national territory [61]. It is located within the popular industrial architecture of the 19th century. It is made up of two buildings. The most important is the one that houses the mill and the house, shaped like an $\mathrm{L}$ and developed on three levels: basement, ground floor and first floor. The main access takes place through the west façade, in front of which we find the other building for the animal stable.

- Constructive characteristics: structure of load bearing walls, masonry and mortar and brick pillars. The floors are made of wood, as are the roof trusses, finished off by Muslim tile.

- State of conservation: the main building for a mill and housing is in good condition; however, the stable is in a dilapidated state.

- $\quad$ Actual use: the main building is used as a museum and an interpretation center for the historic flour factory. It admits school and tourist visits on demand. The original machinery is preserved, and the flour production processes are explained: receiving the wheat, cleaning the grain, milling the wheat, sifting, packing and packaging the final products. The stable is not used.

- Conservation proposals, enhancement and compatible uses: The maintenance of the cultural and educational use of the museum is proposed and the possibility of using the stable as a tourist office for Alhama is offered, after its rehabilitation.

- Photographic documentation.

All the uses proposed in the cards are based on the previous rehabilitation of the existing buildings, respecting the historical exterior volume, the interior distributions, the construction systems, the materials, the levels and the heights. According to the regulations in force in the General Plan of Alhama, in the mills, non-permanent restoration uses, tourist and recreational uses, hydrological protection works and houses linked to agricultural operations can be developed. We propose cultural uses, such as a factory museum, an archaeological museum with the remains found in the Neolithic caves, a library or an archive. The tourist use should be limited to small rural hotels, while the educational one would be aimed at workshop schools and the administrative one for the tourist office (Table 2 and Figures 19-25).

Table 2. Flour factories included in the Mills catalog: summary of their state of conservation and current and proposed uses.

\begin{tabular}{cccc}
\hline Identification & $\begin{array}{c}\text { State of } \\
\text { Conservation }\end{array}$ & Current Use & Proposed Uses \\
\hline $\begin{array}{c}\text { Fca. de harinas San } \\
\text { Francisco (Figure 20) }\end{array}$ & regular & not used & $\begin{array}{c}\text { cultural } \\
\text { educational } \\
\text { tourist }\end{array}$ \\
\hline $\begin{array}{c}\text { Fca. de harinas San Pedro } \\
\text { (Figure 21) }\end{array}$ & in ruins & not used & $\begin{array}{c}\text { cultural } \\
\text { educational } \\
\text { tourist }\end{array}$ \\
\hline $\begin{array}{c}\text { Fca. de harinas La Purísima } \\
\text { (Figures 22 and 23) }\end{array}$ & $\begin{array}{c}\text { mill and house: goods } \\
\text { table: in ruins }\end{array}$ & $\begin{array}{c}\text { cultural (museum) } \\
\text { not used }\end{array}$ & $\begin{array}{c}\text { museum } \\
\text { administrative }\end{array}$ \\
\hline $\begin{array}{c}\text { Fca. de harinas Santa } \\
\text { Teresa (Figure 24) }\end{array}$ & in ruins & not used & $\begin{array}{c}\text { cultural } \\
\text { educational } \\
\text { tourist }\end{array}$ \\
\hline $\begin{array}{c}\text { Fca. de harinas Nuestra } \\
\text { Señora del Carmen } \\
\text { (Figure 25) }\end{array}$ & poor & not used & $\begin{array}{c}\text { cultural } \\
\text { educational } \\
\text { tourist }\end{array}$ \\
\hline
\end{tabular}



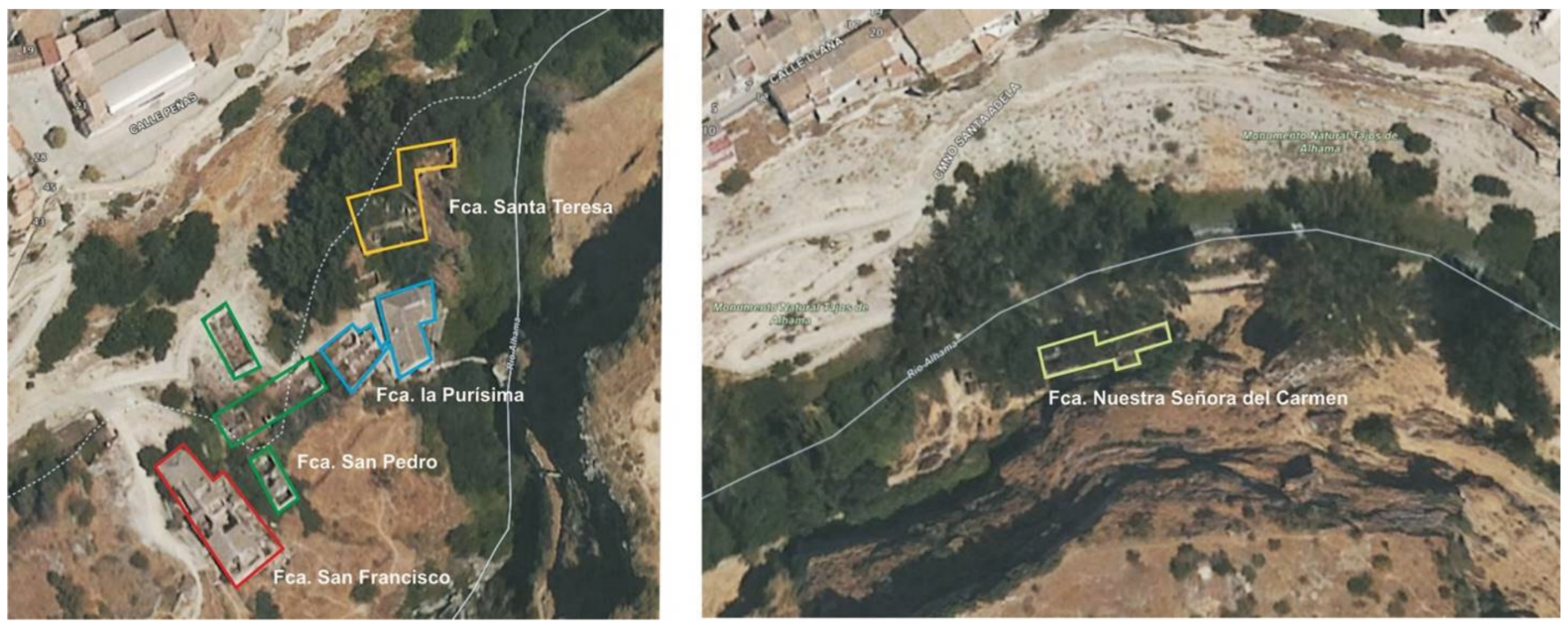

Figure 19. Location map of the mills. Instituto Geográfico Nacional.
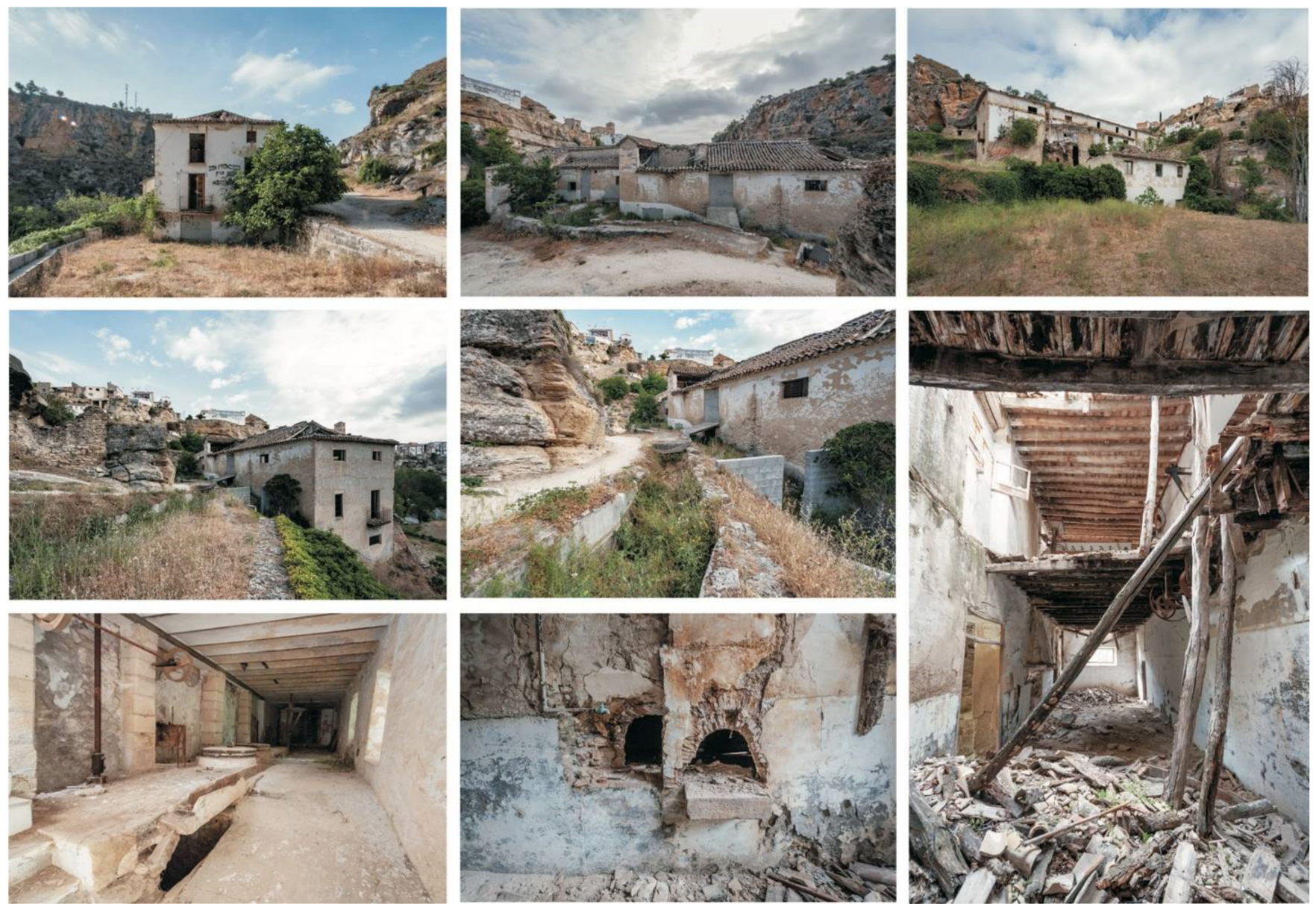

Figure 20. Photographic documentation of the Fábrica de Harinas San Francisco (J.G.M.-S.). 

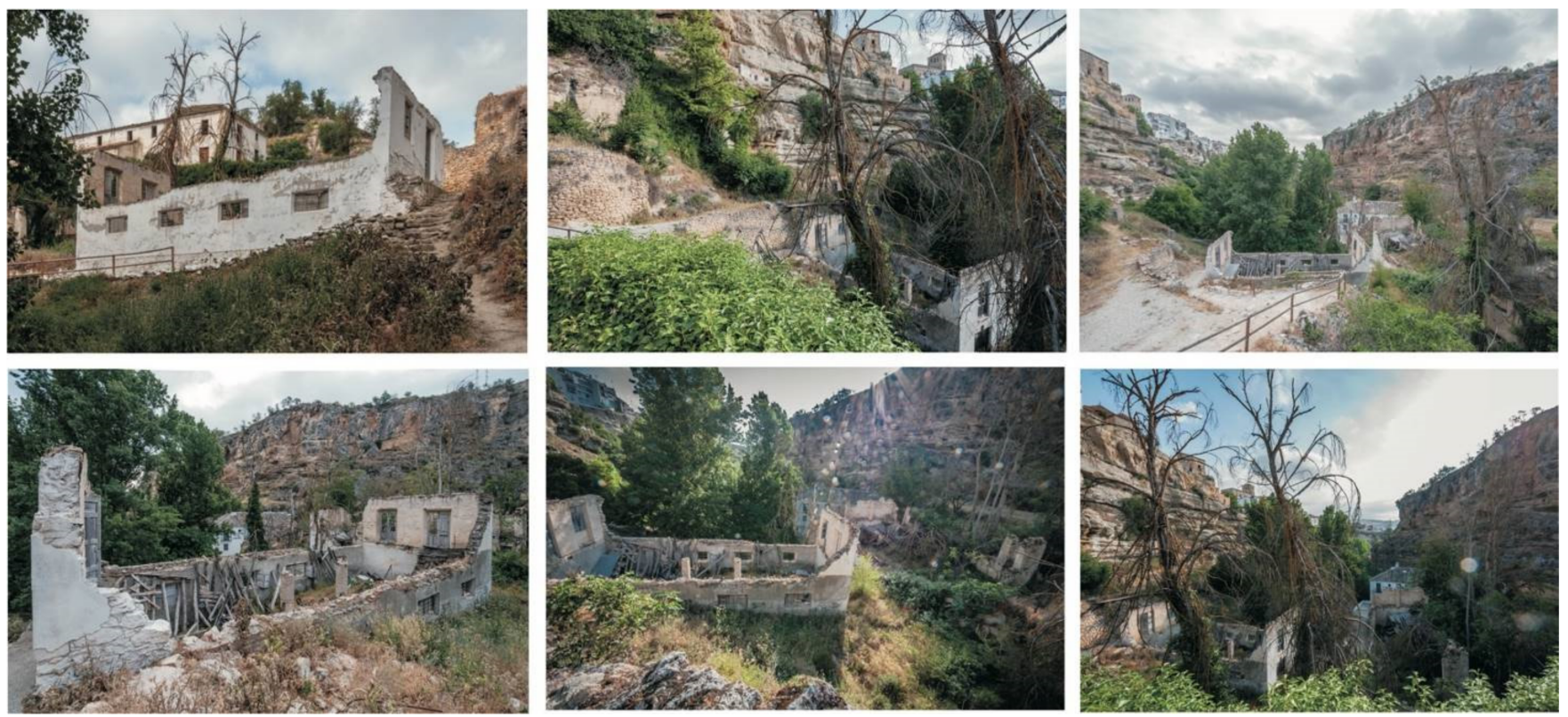

Figure 21. Photographic documentation of the Fábrica de Harinas San Pedro (J.G.M.-S.).
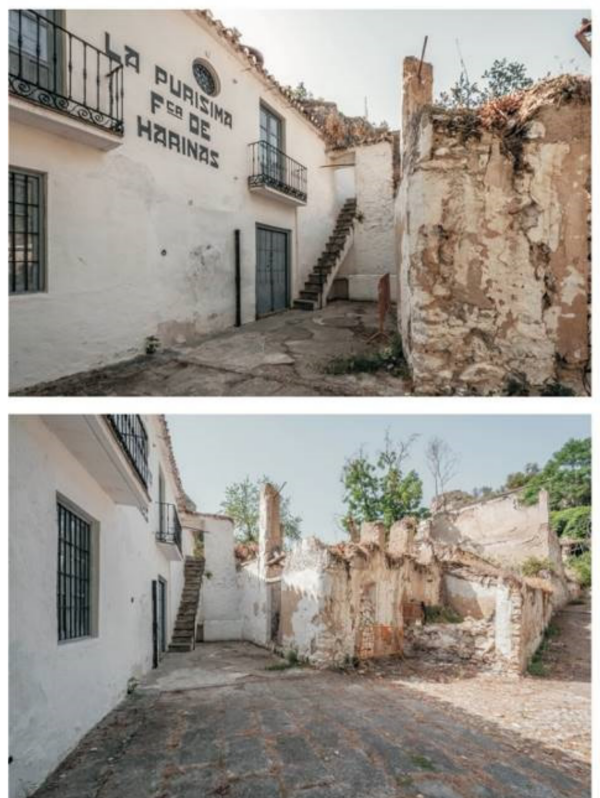

(a)

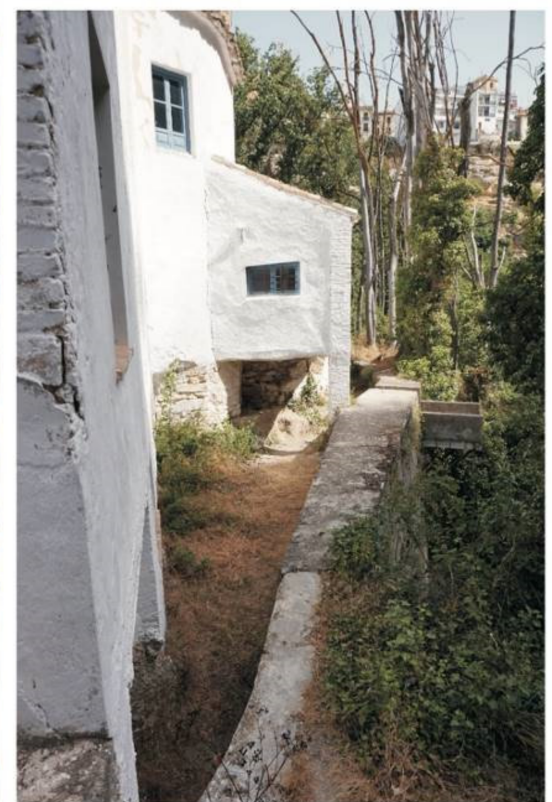

(b)

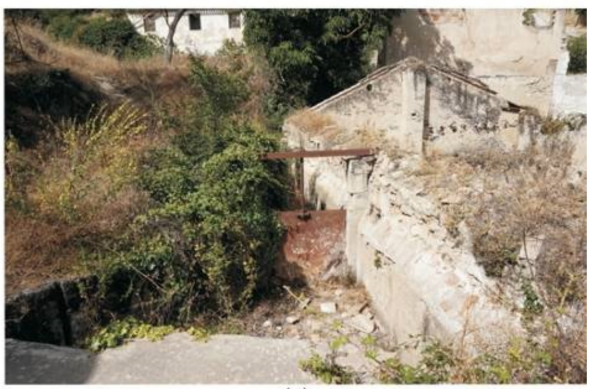

(c)

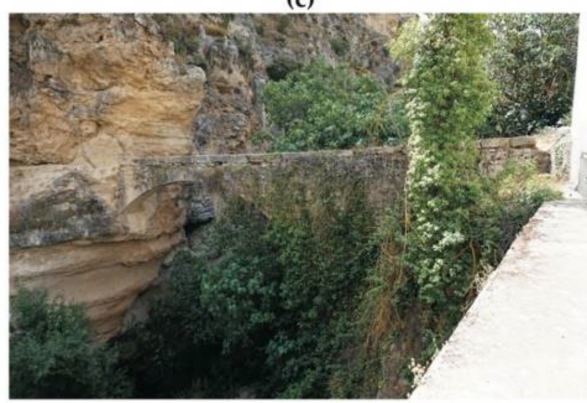

(d)

Figure 22. Photographic documentation of the exterior of the Fábrica de Harinas la Purísima: (a) facade of the main building and the stable in ruins (J.G.M.-S.); (b) rear facade with the Caz del Molino ditch and overflow towards the Marchán River (M.d.C.V.-L.); (c) metal gate in the Caz del Molino ditch next to the stable (M.d.C.V.-L.); (d) 16th century aqueduct next to the mill (M.d.C.V.-L.). 

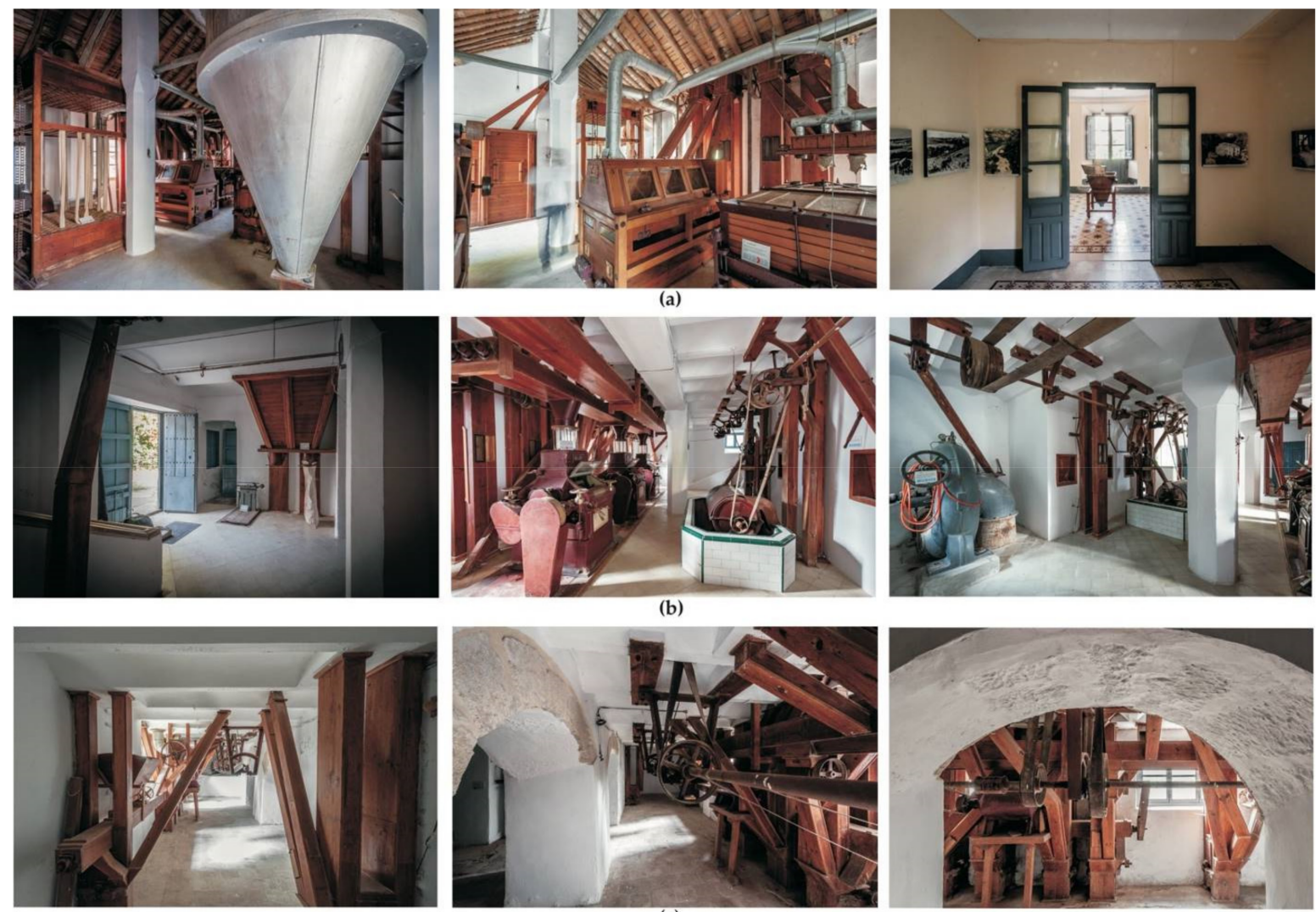

Figure 23. Photographic documentation of the inside of the Fábrica de Harinas la Purísima (J.G.M.-S.): (a) first floor; (b) ground floor; (c) basement.
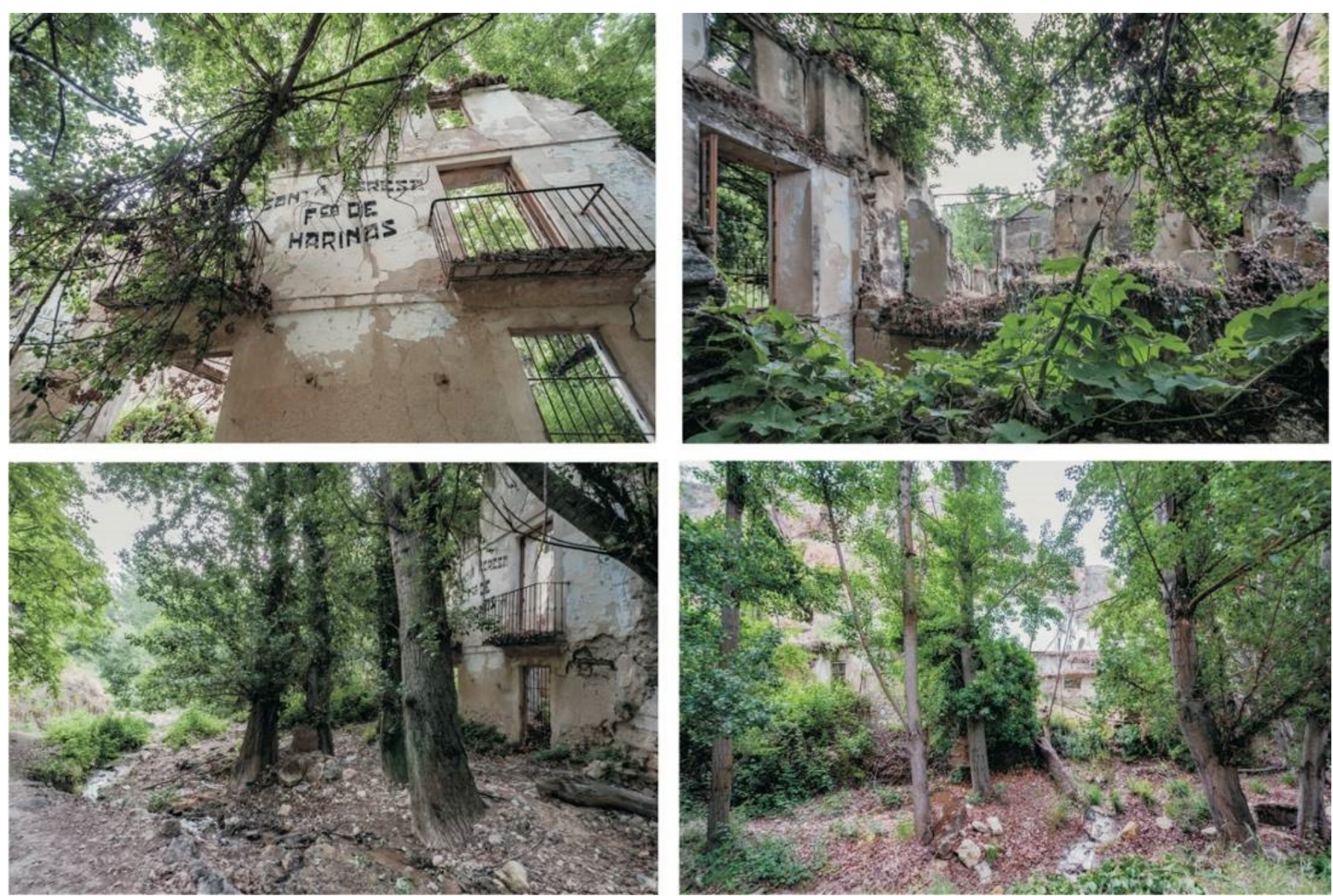

Figure 24. Photographic documentation of the Fábrica de Harinas Santa Teresa (J.G.M.-S.). 

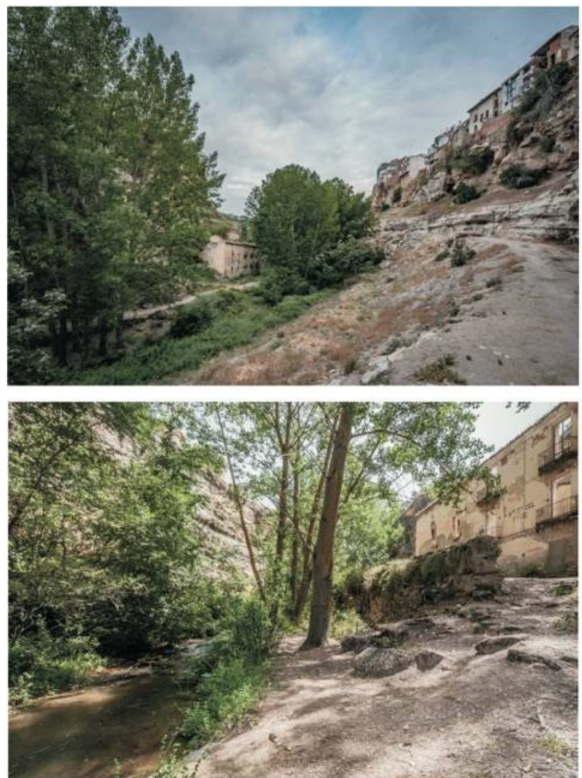

(a)
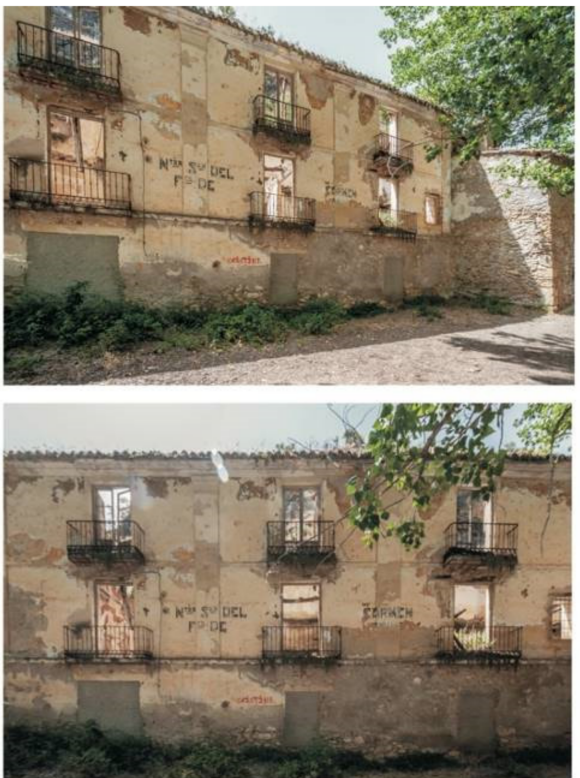

(b)
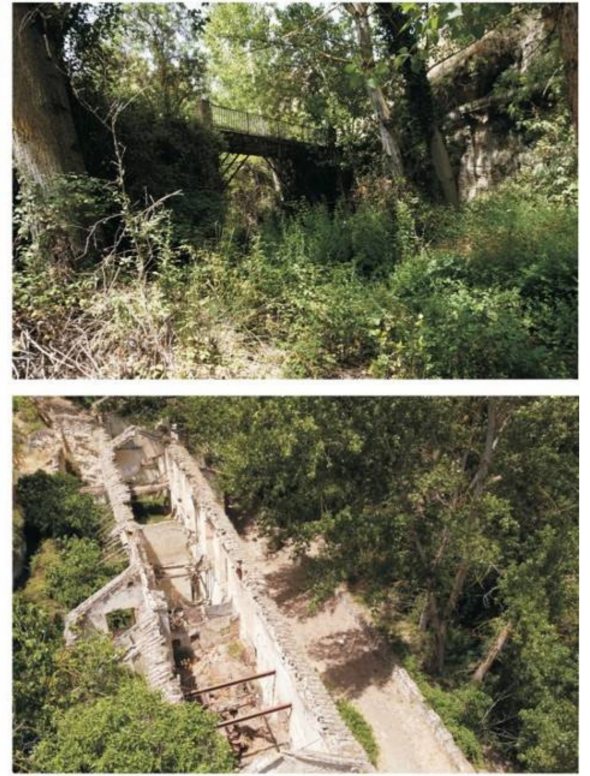

(c)

Figure 25. Photographic documentation of the Fábrica de Harinas Nuestra Señora del Carmen: (a) relationship of the mill with the river (J.G.M.-S.); (b) main facade (J.G.M.-S.); (c) access bridge to the mill and view from above (M.d.C.V.-L.).

\subsection{D Model of the Fábrica de Harinas la Purísima}

The mill of the Fábrica de Harinas la Purísima has been chosen to make a 3D model, together with its closest surroundings, as it is a very valuable example of the sustainable recovery of architectural, cultural and ethnological heritage. It is the only mill preserved in good condition by its owners, including the machinery, being used as an interpretation center and museum. Currently, the mill organizes both school visits and those of tourists who are interested in industrial heritage.

The steps followed to carry out this modeling using SfM photogrammetry have been:

1. Capture of photographic images with the Sony Alfa 5000 camera, hung on a pole, by means of circular sweeps around the mill from different heights to avoid leaving undefined areas.

2. Once the images have been loaded into the software Agisoft PhotoScan, they have been aligned selecting a high precision for the building of the point cloud of the architectural model and its surroundings.

3. We obtain a denser point cloud, increasing the number of pixels with a high resolution.

4. Building of the 3D mesh to obtain the surface geometry of the architectural object.

5. Applying textures to the 3D mesh from the uploaded photos. Agisoft PhotoScan software traces rays from the photos, already oriented, which cut the model, giving it a high-definition texture (Figure 26).

6. The orthophoto of the main façade of the La Purísima mill and its relationship with the surrounding environment has been obtained (Figure 27). 


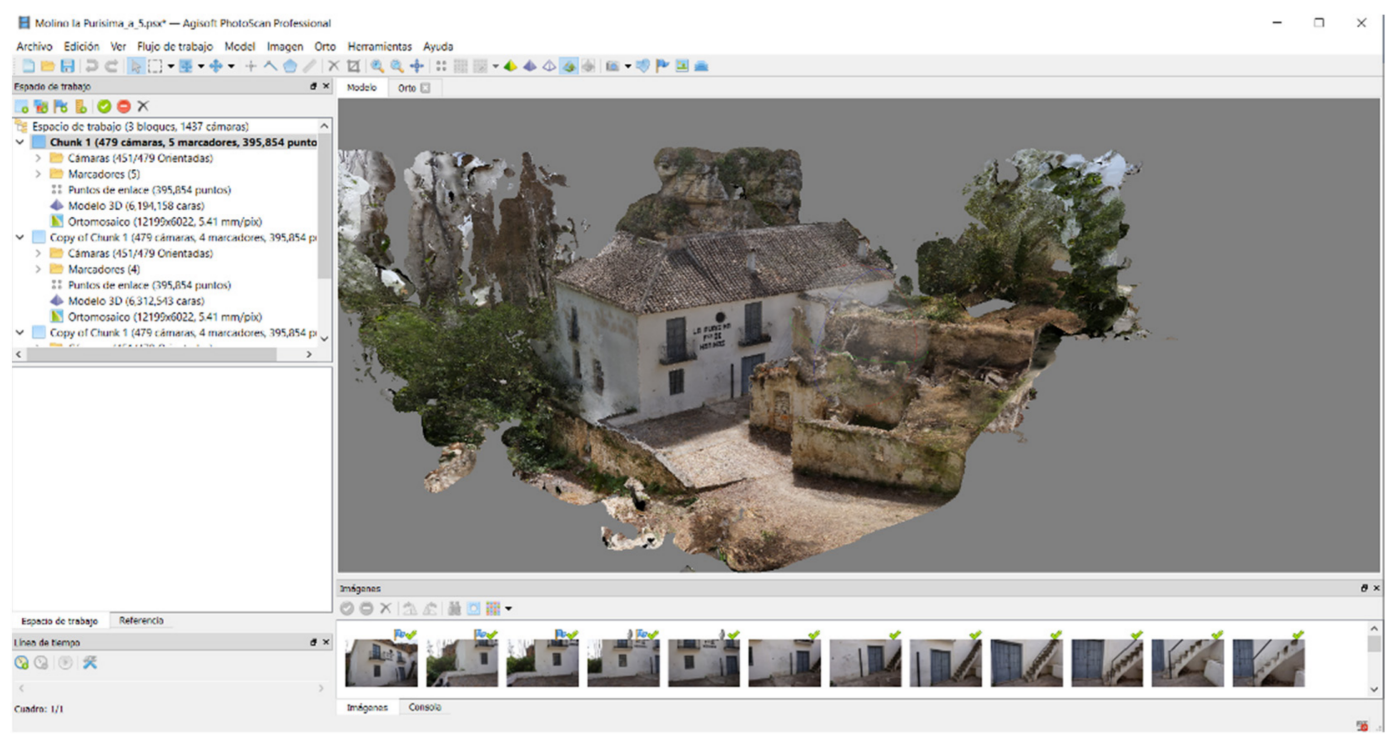

Figure 26. Image obtained from the 3D model once the mesh obtained from the dense point cloud has been textured (M.d.C.V.-L.).

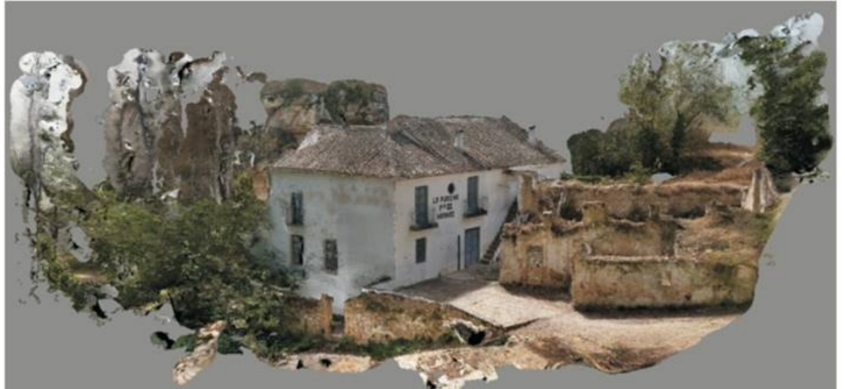

(a)

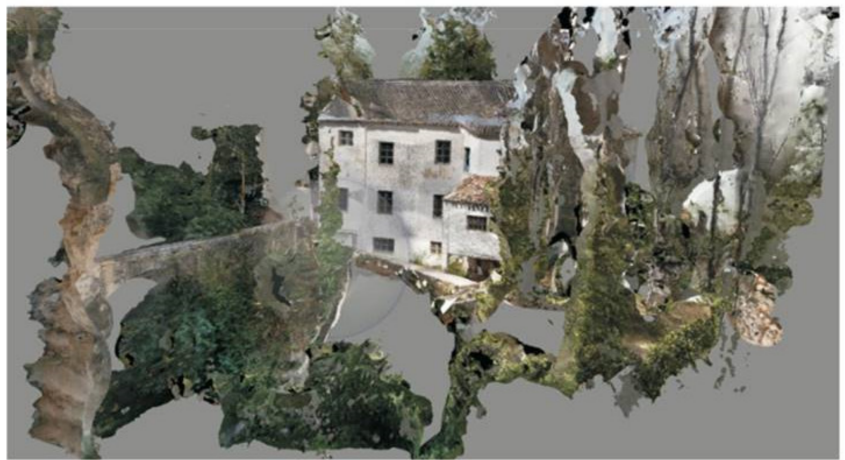

(c)

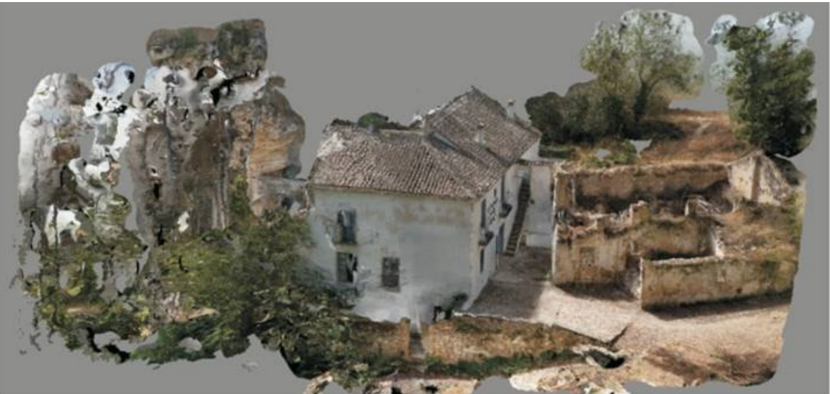

(b)

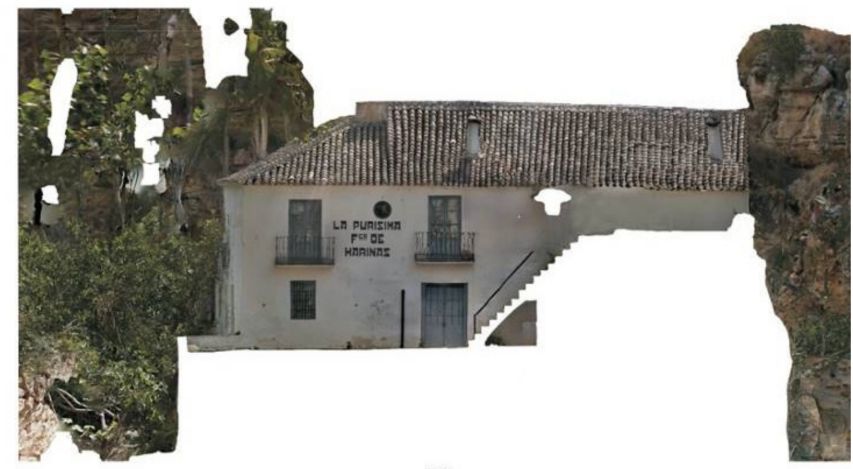

(d)

Figure 27. Views of the 3D model obtained from the Fábrica de Harinas la Purísima and its surroundings (M.d.C.V.-L.): (a) from the access path; (b) between the access road and the river; (c) rear elevation next to the river and the aqueduct; (d) orthophoto of the main facade.

\section{Discussion}

In the review of the previous literature carried out, the exact Roman location of Artigis still generates some controversy. While there are authors who place it on the foundations of the current Alhama, in the Muslim quarter [62] (p. 350), others are inclined to think that the Roman Artigis was very close to the so-called Muslim baths [56,63], whose basement is of Roman construction [64] and next to which there are remains of an old Roman road and a bridge. This bridge, although also called Roman, it can hardly be assured that the 
bridge is from this period due to their architecture and construction [65]. We agree with the hypothesis that defends that the Roman city of Alhama was located in the area of the Cerro de la Mesa del Baño.

After the Visigothic period, it was the Muslims who, in the 9th century, changed the name of the city to Alhama, which means bath (Al Hamma). Moreover, in all probability, it is at this time already that the Alhama location coincides with the current one as it is more rugged given the character of a fortress that we know the city had during the Muladi revolts [63] (p. 12), although it was further from the thermal baths [66]. The visit and written testimony of some Muslim travelers, such as Ibn Battuta, Abd Al-Basit and Al-Malatí [67], confirm that Alhama was an obligatory transit point between Granada, the capital of the emirate, and the coast, concentrating on it being part of business transactions.

Foreign travelers who visited Alhama since the end of the 18th century and in the first half of the 19th century have left valuable written and graphic testimonies of the city of the Tajos, already studied by López-Burgos [68]. Raya [63] (p. 89) affirms that the city had all the ingredients to attract the traveler with a romantic spirit thanks to its rugged setting, its walls with towers, the old castle, the hot springs and the old legends of Moors, Christians and bandits. All this was reflected in the traditional scenes written or drawn by the travelers.

Our research not only provides an updated review of the historical sources but also supplies new graphic documentation (landscape of water, photographic catalog of the mills, photogrammetric survey of the mill-museum Fábrica de Harinas la Purísima) that relates these sources with the cultural landscape of the Tajos de Alhama.

The catalog of mills must serve to present the current state of each one of them and be the first step to the recovery of an architecture in progressive danger of ruin and loss with the deterioration that it entails. According to Rita Fernández [69], conserving and recovering heritage is associated with dignifying the past of our populations, reinforcing their identity, for which the collaboration of citizens is necessary. Beyond the tourist attraction, a sustainable development is sought. Francisco Sánchez defends that, by rescuing these factory buildings from oblivion, we are not only reviving a manufacturing process but also a way of life [70] (p. 7).

The Fábrica de Harinas la Purísima is an example to follow for its cultural and educational work in defense of an intangible, material and ethnological heritage that could disappear if its conservation is not invested in (Figure 28). It has established itself as a cultural and tourist attraction for the city of Alhama, promoting sustainable ecological and cultural tourism. It is currently one of the main heritage landmarks of the Tajos de Alhama.

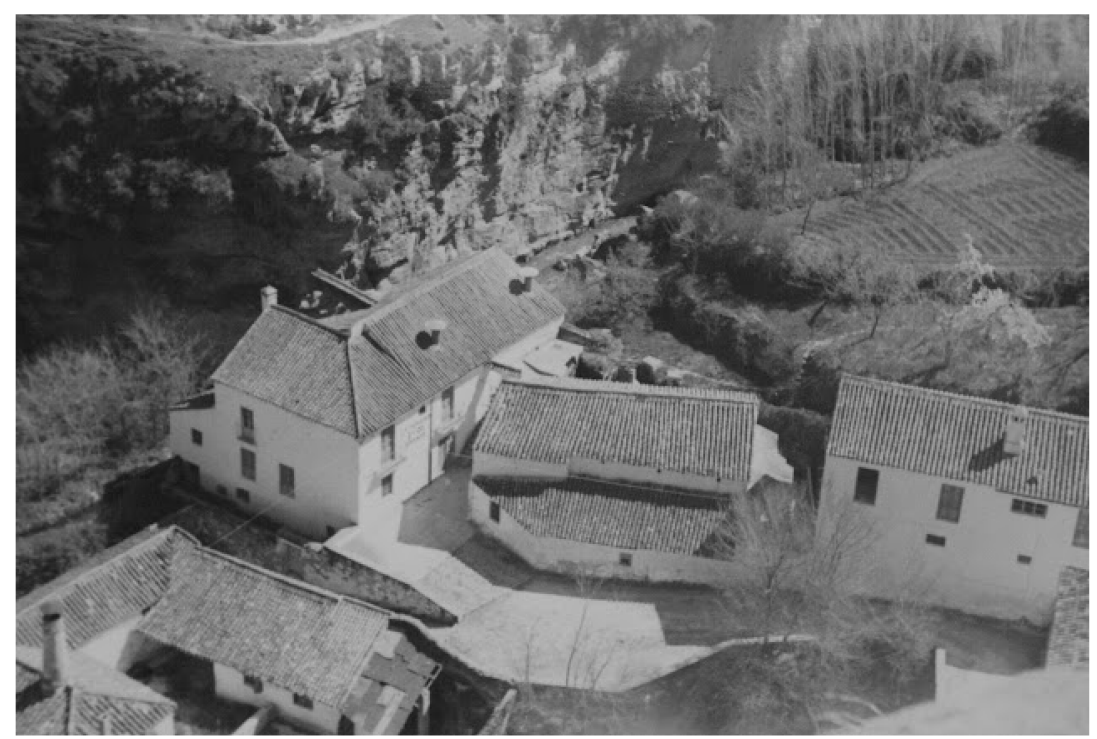

Figure 28. Fábrica de Harinas la Purísima in 1963, next to the Tajo y Alhama River [17]. 


\section{Conclusions}

Alhama is inseparable from its location next to the Tajos, without which it is impossible to understand the historical evolution of the municipality. The landscape values of the Tajos, known as an outstanding landscape and natural monument, must be analyzed from the global vision of a location traversed by the Marchán River to the individual vision of the elements in this landscape, especially the mills, moved by the power of water, an economic engine in the past of the economy of Alhama.

The recovery of the flour infrastructure associated with the water mills would help to generate a focus of cultural and tourist attraction for public or private agents. These actions would mean an improvement for the municipality in the social and economic aspects, favoring not only the sustainable revitalization of a heritage site but also of the historic center, recovering the building heritage.

Museums and interpretation centers, such as the one housed in the Fábrica de Harinas la Purísima, are essential for the dissemination of culture, education and tourism, complementary to the practice or policy of safeguarding the regional and national industrial heritage.

Regarding the landscape of water, we can affirm that the presence of the Marchán River in this territorial area, together with the natural water conductions (ravines and streams) and artificial (reservoirs, dams and ditches) have generated a spectacular cultural landscape in their passage through the Tajos de Alhama, which must be protected, avoiding the progressive deterioration of the most sensitive areas. An important variety of fauna or vegetation has also developed in this ecosystem.

In our opinion, the research carried out in the Tajos de Alhama de Granada, with regard to the methodology and materials used, could be extended to other similar cultural and heritage landscapes, such as those existing in the Spanish cities of Ronda and Cuenca, which are also closely linked to their urban nuclei.

Author Contributions: Conceptualization, M.d.C.V.-L.; methodology, M.d.C.V.-L., J.G.M.-S. and C.R.-M.; software, M.d.C.V.-L. and C.R.-M.; validation, M.d.C.V.-L., J.G.M.-S. and C.R.-M.; formal analysis, M.d.C.V.-L.; investigation, M.d.C.V.-L.; resources, M.d.C.V.-L.; data curation, M.d.C.V.-L., J.G.M.-S. and C.R.-M.; writing-original draft preparation, M.d.C.V.-L.; writing-review and editing, M.d.C.V.-L.; visualization, M.d.C.V.-L., J.G.M.-S. and C.R.-M.; supervision, M.d.C.V.-L., J.G.M.-S. and C.R.-M.; project administration, M.d.C.V.-L., J.G.M.-S. and C.R.-M.; funding acquisition, C.R.-M. All authors have read and agreed to the published version of the manuscript.

Funding: This research was funded by Department of Architectural and Engineering Graphic Expression, University of Granada.

Institutional Review Board Statement: Not applicable.

Informed Consent Statement: Not applicable.

Data Availability Statement: Data are contained within the article.

Acknowledgments: The authors thank the Alhama de Granada Tourist Office and the Castro family for opening the Fábrica de Harinas la Purísima for their visit and data collection.

Conflicts of Interest: The authors declare no conflict of interest.

\section{References}

1. Diccionario de la lengua española. Available online: https:/ / dle.rae.es/tajo (accessed on 29 July 2021).

2. Cambridge Dictionary. Available online: https://dictionary.cambridge.org/es/diccionario/ingles/gorge (accessed on 29 July 2021).

3. Decreto 2973/1975, 31 October. BOE 284, 26 November 1975. Available online: https://www.boe.es/diario_boe/txt.php?id= BOE-A-1975-24272 (accessed on 10 June 2021).

4. Decreto 192/2011, 7 June. BOJA 126, 29 June 2011. Available online: https://www.juntadeandalucia.es/boja/2011/126/14 (accessed on 10 June 2021). 
5. Decreto 382/2011, 30 December. BOJA 8, 13 January 2012. Available online: https://www.juntadeandalucia.es/boja/2012/8/6 (accessed on 10 June 2021).

6. Resolución 14 February 2007, de la Dirección General de Urbanismo, por la que se dispone la publicación del Plan Especial de Protección del Medio Físico y Catálogo de Espacios y Bienes Protegidos de la provincia de Granada. BOJA 61, 27 March 2007. Available online: https:/ / www.juntadeandalucia.es/boja/2007/61/boletin.61.pdf (accessed on 26 July 2021).

7. Molinero-Sánchez, J.G. Los Tajos de Alhama de Granada. Los molinos. In ReUSO, Sobre Una Arquitectura Hecha de Tiempo; Palma, M., Gutiérrez, M.L., García, R., Eds.; Universidad de Granada: Granada, Spain, 2017; Volume 3, pp. $285-292$.

8. Gila Medina, L. Alhama de Granada. Patrimonio Artístico y Urbano; Excelentísimo Ayuntamiento de Alhama de Granada: Alhama de Granada, Spain, 2003.

9. Clavero Salvador, M. Guía Oficial del Parque Natural Sierras de Tejeda, Almijara y Alhama; Almuzara: Jaén, Spain, 2011.

10. Fernández-Baca Casares, R. Vega de Granada-Alhama. In Paisajes y Patrimonio Cultural en Andalucía. Tiempo, Usos e Imágenes; Junta de Andalucía, Consejería de Cultura: Sevilla, Spain, 2010; Volume 2, pp. 600-619.

11. Raya Retamero, S. Catastro de la Ensenada, Alhama de Granada I. Respuestas a las Preguntas Generales; Ediciones Calcomanía: Granada, Spain, 1997.

12. Madoz, P. Diccionario Geográfico-Estadístico-Histórico de España y Sus Posesiones de Ultramar; Establecimiento tipográfico de P. Madoz y L. Sagasti: Madrid, Spain, 1845; Volume 1.

13. Gutiérrez Arenas, J. Los Hijos de Lucas Gutiérrez López. Una Historia de la Gente de Alhama de Granada; Ediciones la Peña: Granada, Spain, 2012.

14. Turriano, J. Los Veintiún Libros de los Ingenios y Máquinas, tomo III; Fundación Juanelo Turriano: Madrid, Spain, 1996.

15. Reyes Mesa, J.M. Tecnología y arquitectura popular. Los molinos hidráulicos en la provincia de Granada. Gazeta Antropología 2000, 16, 1-13. [CrossRef]

16. Moreno Vega, A.; López Gálvez, M.Y. Las Harineras Cordobesas: Historia, Tecnología y Arquitectura (Siglos XIX-XX); A. Moreno Vega: Córdoba, Spain, 2011.

17. Fca de Harinas la Purísima. Available online: https:/ / www.fcalapurisima.com (accessed on 25 August 2021).

18. Papapietro, M.A. Proyección paisajística del patrimonio industrial en Andalucía. In Jornadas Andaluzas de Patrimonio Industrial y de la Obra Pública. 25, 26, 27 Noviembre 2010; Fundación Patrimonio Industrial de Andalucía: Sevilla, Spain, $2012 ;$ pp. 1-9.

19. Reinoso-Gordo, J.F.; Barsky, D.; Serrano-Ramos, A.; Solano-García, J.A.; León-Robles, C.A.; Luzón-González, C.; Titton, S.; Jiménez-Arenas, J.M. Walking among Mammoths. Remote Sensing and Virtual Reality Supporting the Study and Dissemination of Pleistocene Archaeological Sites: The Case of Fuente Nueva 3 in Orce, Spain. Sustainability 2020, 12, 4785. [CrossRef]

20. Orihuela, A.; Molina Fajardo, M.A. UAV Photogrammetry Surveying for Sustainable Conservation: The Case of Mondújar Castle (Granada, Spain). Sustainability 2021, 13, 24. [CrossRef]

21. Marín-Buzón, C.; Pérez-Romero, A.; López-Castro, J.L.; Jerbania, I.B.; Manzano-Agugliaro, F. Photogrammetry as a New Scientific Tool in Archaeology: World Research Trends. Sustainability 2021, 13, 5319. [CrossRef]

22. Macpherson, G. La Cueva de la Muger: Descripción de Una Caverna Conteniendo Restos Prehistóricos, Descubierta en las Inmediaciones de Alhama de Granada; Imprenta de la Revista Médica: Cádiz, Spain, 1870.

23. García Sánchez, M.; Jiménez Brobeil, S.A. Restos humanos neolíticos de Alhama de Granada. Cuad. Prehist. Univ. Granada 1985, 10, 67-101.

24. Pellicer Catalán, M. Actividades de la Delegación de la Zona de la provincia de Granada durante los años 1957-1962. Not. Arqueol. Hispánico 1964, VI, 304-350.

25. Navarrete Enciso, M.S. La cultura de las cuevas con cerámica decorada en Andalucía Oriental. Cuad. Prehist. Univ. Granada 1976, 1, 59-73.

26. Navarrete Enciso, M.S.; Carrasco Rus, J.; Gámiz Jiménez, J.; Jiménez, S. La cueva de los Molinos (Alhama, Granada). Cuad. Prehist. Univ. Granada 1985, 10, 31-65.

27. Cortés y López, M. Diccionario Geográfico-Histórico de la España Antigua Tarraconense, Bética y Lusitana, con la correspondencia de sus regiones, ciudades, montes, ríos, caminos, puertos e islas a las conocidas en nuestros días; Tomo, I., Ed.; Imprenta Real: Madrid, Spain, 1835.

28. Bejarano, V. Hispania Antigua según Pomponio Mela, Plinio el Viejo y Claudio Ptolomeo; Instituto de Arqueología y Prehistoria: Barcelona, Spain, 1987; Volume VII.

29. Münzer, J.; Puyol y Alonso, J. Viaje por España y Portugal en los años 1494 y 1495. Boletín Real Acad. Hist. 1924, 84, 32-119.

30. Di Stefano, G. Los textos del Romance del Rey Moro que perdió Alhama en las fuentes del siglo XVI. In Estudios de folklore y literatura dedicados a Mercedes Díaz Roig; El Colegio de México: Mexico City, México, 1992; pp. 41-52.

31. Arenas Maestre, A. El más famoso de los romances fronterizos en inglés, francés y alemán. In Día Histórico de Alhama; Patronato de Estudios Alhameños: Alhama de Granada, Spain, 2014; pp. 28-31.

32. Ares Montes, J. Duarte Dias, cantor de la conquista de Granada. Rev. Filol. Románica 1984, 2, $19-36$.

33. Irving, W. A Chronicle of the Conquest of Granada from the Mss. of Fray Antonio Agapida; John Murray: London, UK, 1823.

34. Durán y Lerchundi, J. La toma de Granada y caballeros que concurrieron á ella; Imprenta y litografía de los Huérfanos: Madrid, Spain, 1893.

35. Franco Mata, A. El Coro de la Catedral de Toledo. Abrente 2010, 42, 113-166. 
36. Gil Sanjuán, J.; Sánchez López, J.A. Iconografía y visión histórico-literaria de Granada a mediados del quinientos. Chronica Nova 1996, 23, 73-133.

37. García Maldonado, A. Las Vistas Panorámicas de Alhama de Hoefnagel y Van den Wyngaerde; Excelentísimo Ayuntamiento de Alhama de Granada: Alhama de Granada, Spain, 1999.

38. Kagan, R.L. Ciudades del Siglo de Oro. Las Vistas Españolas de Anton van den Wyngaerde; El Viso: Madrid, Spain, 1986.

39. Espigares Rooney, B. Contemporary chorographies of Granada. Research through drawing and its possible unexpected results. EGA 2014, 23, 70-79. [CrossRef]

40. Vílchez Lara, M.C. Graphics Techniques in the projects of the University of Granada. A route from Enlightenment to Autarchy. EGA 2019, 24, 106-115. [CrossRef]

41. Hondius, I. Gerardi Mercatoris Atlas Sive Cosmographicae Meditations de fabrica Mundi et Fabricate Figura; Patrimonio digital Complutense: Madrid, Spain, 1623; Available online: http:/ /dioscorides.ucm.es/proyecto_digitalizacion/index.php?5325594869 (accessed on 30 July 2021).

42. Texeira, P. Tabla del Reyno de Andaluzia. Cartoteca Histórica digital de Extremadura, Spain, 1634. Available online: http: / / sitex.gobex.es/SITEX/pages / cartoteca?page=ficha\&fid=452 (accessed on 30 July 2021).

43. Townsend, J. A Journey Through Spain in the Years 1786 y 1787; C. Dilly: London, UK, 1792.

44. Ponz, A.; Ponz, J. Viage de España: En que se da Noticia de las Cosas mas Apreciables, y Dignas de Saberse, Que Hay en Ella, tomo XVIII; Viuda de D. Joaquín Ibarra: Madrid, Spain, 1794.

45. Semple, R. A Second Journey in Spain in the Spring of 1809, From Lisbon through the Western Skirts of the Sierra Morena, to Sevilla, Cordoba, Granada, Malaga, and Gibraltar; and thence to Tetuan and Tangier, 2nd ed.; Robert Baldwin: London, UK, 1812.

46. Jacob, W. Travels in the South of Spain in Letters Written A.D. 1809 and 1810; J. Johnson: London, UK, 1811.

47. Scott, C.R. Excursions in the Mountains of Ronda and Granada: With Characteristic Sketches of the Inhabitants of the South of Spain; Henry Colburn: London, UK, 1838.

48. Ford, R. A Hand-Book for Travellers in Spain and Readers at Home; John Murray: London, UK, 1845.

49. Gautier, T. Voyage en Espagne; Chanpentier: Paris, France, 1845.

50. Tenison, L. Castile and Andalucia; Richard Bentley: London, UK, 1853.

51. Udías, A.; Muñoz, D. The Andalusian earthquake of 25 December 1884. Tectonophysics 1979, 53, 291-299. [CrossRef]

52. López Arroyo, A.; Martín Martín, A.J.; Mezcua Rodríguez, J. Terremoto de Andalucía: Influencia en sus efectos de las condiciones del terreno y del tipo de construcción. In El Terremoto de Andalucía del 25 de diciembre de 1884; Instituto Geográfico Nacional: Madrid, Spain, 1981; pp. 5-94.

53. Vidal Sánchez, F. El Terremoto de Alhama de Granada y su impacto. Anuari Verdaguer 2011, 19, 11-45.

54. Benítez Ortúzar, I.F. La comarca de Alhama vista por un catalán. In Día Histórico de Alhama; Patronato de Estudios Alhameños: Alhama de Granada, Spain, 2010; pp. 13-16.

55. Moya Castillo, C. La temblorosa Alhama. In Día Histórico de Alhama; Patronato de Estudios Alhameños: Alhama de Granada, Spain, 2010; pp. 24-25.

56. García Maldonado, A. Estudio Histórico. In Plan General de Ordenación Urbanística Alhama de Granada, 6; Excelentísimo Ayuntamiento de Alhama de Granada: Alhama de Granada, Spain, 2010; pp. 5-56.

57. Inventario de Humedades de Andalucía: Pantaneta de Alhama. Código IHA614014. Available online: https://www. juntadeandalucia.es/medioambiente/portal/ documents /20151/11283696/IHA614014.pdf/0cac6dfa-b742-4f93-2e9b-6445c7 30004a?t=1619513286282 (accessed on 28 September 2021).

58. García Maldonado, A. El transvase río Alhama-Pantano de los Bermejales. In Día Histórico de Alhama; Patronato de Estudios Alhameños: Alhama de Granada, Spain, 2011; p. 15.

59. Gordo Villaraso, A. El río y yo. In Día Histórico de Alhama; Patronato de Estudios Alhameños: Alhama de Granada, Spain, 2018; p. 27.

60. Zoido Naranjo, F.; Jiménez Olivencia, Y. Catálogo de Paisajes de la Provincia de Granada; Centro de Estudios Paisaje y Territorio, Consejería de Medio Ambiente y Ordenación del Territorio: Sevilla, Spain, 2015.

61. Molinero Sánchez, J.G. Proyecto del Curso Superior de Métodos y Técnicas Para la Documentación e Información del Patrimonio Cultural; Instituto Andaluz del Patrimonio Histórico: Sevilla, Spain, 2015.

62. Ceán Bermúdez, J.A. Sumario de las Antigüedades Romanas que hay en España, en Especial las Pertenecientes á las Bellas Artes; Imprenta de Miguel de Burgos: Madrid, Spain, 1832.

63. Raya Retamero, S. Guía Histórico-Artística de Alhama de Granada; Grupo de Investigación Filosofía y Antropología de la Universidad de Granada: Granada, Spain, 2007.

64. Vílchez Vílchez, C. Baños Árabes; Diputación de Granada: Granada, Spain, 2004.

65. Aznar Pérez, J.C. Carta Arqueológica Alhama de Granada; Ayuntamiento de Alhama de Granada: Alhama de Granada, Spain, 2006.

66. Manzano Martos, R. Baño termal de Alhama de Granada. Al-Andal. Rev. Esc. Estud. Árabese Madr. Granada 1958, $23,408-416$.

67. García Maldonado, A. Milenios de historia para la Alhama de siempre. In Día Histórico de Alhama; Patronato de Estudios Alhameños: Alhama de Granada, Spain, 2010; pp. 35-40.

68. López Burgos, M.A. Por Tierras de Alhama-Temple: Relatos de Viajeros Ingleses (1809-1852); Ayuntamiento de Alhama de Granada: Alhama de Granada, Spain, 1997. 
69. Fernández Moles, R. Declaración: La Asociación de Amigos de Alhama de Granada y nuestra implicación con el Patrimonio de la Comarca. Çibdad Miscelánea Hist. Arte Lit. Folc. Alhama Comarc. 2017, 2, 15-22.

70. Sánchez Sánchez, F.J. El patrimonio arquitectónico azucarero en Andalucía Oriental. Intervenciones y nuevos usos. E-Rph Rev. Electrónica Patrim. Histórico 2009, 5, 3-42. 